\title{
Dissimulation in Sunni Islam and Morisco Taqiyya*
}

\section{La disimulación en el islam sunní y la taqiyya morisca}

\author{
Devin Stewart \\ Emory University, Atlanta, EEUU
}

\begin{abstract}
Este trabajo ofrece un resumen de la doctrina religiosa de taqiyya o disimulación en el islam sunní, recurriendo a comentarios del Qur’ān, compendios de hadīt, obras de ley islámica y tratados de principios éticos. En las fuentes andalusíes antes de la conquista cristiana aparecen discusiones acerca del concepto de $t a$ qiyya y del de coerción (ikrāh), ambos exenciones legales, y algunas de ellas continuaron estando a disposición de los moriscos y de los juristas norteafricanos que les aconsejaban. El análisis de estos materiales facilita la interpretación de la fatwā que Ibn Abì Ŷum a al-Wahrānī envió a los moriscos en el año 1504 y particularmente la comprensión de su tratamiento de la blasfemia bajo coacción.

Palabras clave: moriscos; disimulo; taqiyya; coacción; ikrāh; blasfemia; paronomasia.
\end{abstract}

This study provides an outline of the religious doctrine of taqiyya or dissimulation in Sunni Islam, drawing on Qur'ānic commentaries, hadith compilations, legal manuals, and ethical treatises. Moriscos and the North African jurists who advised them had access to discussions of taqiyya and the closely connected legal dispensation of coercion ( $i k r a \bar{h})$ through these sources, many of which were wellknown in al-Andalus before the Reconquista, and some of which continued to be popular afterwards. Attention to this material helps one to interpret the 1504 fatwa of Ibn Abì Jum 'a al-Wahrānī to the Moriscos and in particular his discussion of blasphemy under coercion.

Key words: Moriscos; Dissimulation; Taqiyya; Coercion; Ikrāh; Blasphemy; Paronomasia.

... car la dissimulation est des plus notables qualitez de ce siècle.

Montaigne, $1580^{1}$

Zagorin's fascinating study of dissimulation in sixteenth-century Europe exhibits a curious lacuna. During this period widespread religious, ideological conflicts and increasingly intense efforts on the part

* Parts of this study were presented at the Middle East Studies Association, Phoenix, Arizona, November, 1994; Islamic Law Conference at Hebrew University, January, 2000; the European Studies Colloquium at Emory University, March, 2006; and the Conference on Hybridity in al-Andalus, University of Wisconsin, Madison, October 2007. I would like to thank Maribel Fierro, Mercedes García-Arenal, Yohanan Friedmann and Etan Kohlberg in particular for their valuable comments and suggestions.

${ }^{1}$ Montaigne, "Du dementir", vol. 2, p. 70. 
of political and religious authorities to enforce doctrinal conformity led to heightened and increasingly sophisticated uses of dissimulation, drawing on disciplines of dissimulation formulated in theoretical terms and sometimes recorded in manuals for neophyte dissimulators. With the theoretical attention drawn to these matters also came a heightened focus on language and its capacity to provide reliable evidence or, alternatively, to conceal inner thoughts and convictions. ${ }^{2}$ The documentary net of Zagorin's research was cast quite widely, catching nearly all the examples one might expect: the crypto-Judaism of conversos in Spain and Portugal, the Nicodemism of Protestants in Catholic Italy, the Catholicism of recusants in England, the mental reservation of the Catholic doctors, and even the dissimulation of occultists and liberal philosophers. Absent in this litany of notorious dissimulators, however, are the Moriscos, the Muslims of Spain who underwent forced conversions to Catholicism in 1501-02 in Castile and 1526 in Valencia, many of whom continued to hold fast to their faith in secret until the final expulsions of 1609-14. The oversight is odd, given that the predicament of the Moriscos was quite similar, if not exactly parallel, to that of the conversos, to whom Zagorin devotes an entire chapter. The omission is all the more surprising when one notes that Zagorin in fact draws attention to the existence of an Islamic discipline of dissimulation, termed taqiyya, mysteriously claiming that it is instructive for his study but not relevant to the European context: "An interesting case of dissimulation for religious reasons is provided by a historical instance lying far afield from Europe that nevertheless serves well to illustrate its character". ${ }^{3}$ He alludes here to the tradition of dissimulation in the Shi ${ }^{-1}$ ite sect of Islam. ${ }^{4}$ In a footnote, he half-heartedly justifies the omission of Moriscos, attempting to distinguish them, on the grounds that they often lived apart in separate villages and quarters and so did not need to conceal their practices, from the conversos, who held higher positions in society and were more learned and better integrated into Christian society. ${ }^{5}$ The argument falls flat; although many Moriscos were

2 Maclean, Meaning and Interpretation in the Renaissance: The Case of Law.

${ }^{3}$ Zagorin, Ways of Lying: Dissimulation, Persecution and Conformity in Early Modern Europe, p. 3.

${ }^{4}$ Zagorin, Ways of Lying, pp. 3-5; Donaldson, The Shi' ite Religion: A History of Islam in Persia and Irak; Tabataba'i, Shiite Islam.

${ }^{5}$ Zagorin, Ways of Lying, p. 41 n. 5. 
simple peasants, in Granada and elsewhere they included people from all walks of life, including the privileged, the powerful, and the learned. Many were highly integrated into Christian society, and even more were under regular scrutiny and surveillance by neighbors as well as the authorities. The main reasons for Zagorin's omission are two: modern scholars' conviction that the Moriscos, as Sunni Muslims, did not have available to them the doctrinal option of taqiyya and the dearth of published studies on taqiyya in Sunni Islam.

Many discussions of the Moriscos of Spain have suggested that they consciously dissimulated with recourse to the Islamic legal concept of taqiyya. ${ }^{6}$ While it has always been recognized that large numbers of Moriscos practiced dissimulation after their forced conversions in the early sixteenth century, the ideas that this behavior was justified in Islamic doctrinal terms and that the Moriscos who were dissimulating knew of the Islamic legal dispensation to do so remain unevenly accepted and inadequately supported. This study investigates the theoretical background of Morisco dissimulation through examination of the well-known legal responsum issued by Ibn Abī Jum a al-Maghrāwī alWahrānī for the Moriscos of Granada in 910/1504 as well as other Islamic texts that would have been accessible in Spain and North Africa, arguing that taqiyya forms part of standard Sunni doctrine, overlapping to a large extent with the related legal dispensation of $i k r a \bar{h}$ "coercion, duress, compulsion". Sunni authors sometimes avoid use of the term taqiyya itself, perhaps because of its association with Shie ism in particular, but their detailed discussions of $i k r a \bar{h}$ closely resemble discussions

${ }^{6}$ Harvey, "Crypto-Islam in Sixteenth-Century Spain"; Harvey, "The Political, Social and Cultural History of the Moriscos"; Harvey, Muslims in Spain, 1500-1614, pp. 60-64; Harvey, "Una referencia explícita a la legalidad de la práctica de la taqiya por los moriscos"; Cardaillac, Morisques et Chrétiens: un affrontement polémique (1492-1640); Cardaillac, "Un aspecto de las relaciones entre moriscos y cristianos: polémica y taqiyya"; García-Arenal, Inquisición y Moriscos: Los procesos del Tribunal de Cuenca, pp. 101-02; Vernet, "La exégesis musulmana tradicional en los coranes aljamiados", p. 125; Chejne, Islam and the West: The Moriscos, A Cultural and Social History, p. 24; Galmés de Fuentes, Los moriscos (desde su misma orilla), pp. 108-13; Tueller, Good and Faithful Christians: Moriscos and Catholicism in Early Modern Spain, pp. 62-63; Barletta, Covert Gestures: Crypto-Islamic Literature as Cultural Practice in Early Modern Spain, pp. xxviii-xxix; Perry, The Handless Maiden: Moriscos and the Politics of Religion in Early Modern Spain, pp. 34-35; Miller, Guardians of Islam: Religious Authority and Muslim Communities of Late Medieval Spain, pp. 114, 181; Ibrahim, "Literature of the Converts in Early Modern Spain: Nationalism and Religious Dissimulation of Minorities", pp. 210, 220. 
of taqiyya. Both concepts appear in standard Sunni texts of law, hadith, and Qur'ānic exegesis that would have been available to North African and Andalusian jurists of the Mālikī legal tradition who advised the Moriscos regarding their religious obligations. Therefore, Moriscos would have known of the Islamic legal justification for dissimulation, and some of them, at least, consciously applied an Islamic discipline of dissimulation to their interactions with Church authorities, the Inquisition, state officials, and the surrounding Christian society at large.

In 1964, L.P. Harvey called attention to taqiyya in sixteenth century Spain, labelling the Moriscos' faith "crypto-Islam". His analysis suggests, however, that the use of the dispensation of taqiyya on the part of the Moriscos was surprising. Glossing taqiyya as "circumspect denial of one's true beliefs when in danger", he notes that the concept developed early in Islamic history and has been used primarily by heterodox Muslims, especially Shīites threatened by a Sunni majority. He adds that the practice of taqiyya has been thought of as an exception applying to individuals and not to an entire community. ${ }^{7}$ Dressendörfer similarly portrays taqiyya as a major facet of Morisco belief and practice in his work on the Inquisition's trials of Moriscos in Toledo in the late sixteenth and early seventeeth centuries. ${ }^{8}$ In his 1977 work on polemic between Moriscos and Christians, Louis Cardaillac identifies taqiyya as the Moriscos' main defense against the Inquisition and a fundamental facet of their beliefs and practice. Reference to the Islamic concept of taqiyya has been described as an almost ritual obligation in studies devoted to the Moriscos since Cardaillac's work. ${ }^{9}$ In contrast, Mercedes García-Arenal suggests that the behavior of the Moriscos of Cuenca may have had more to do with the force of circumstances than with knowledge of religious doctrine. ${ }^{10}$ Cardaillac notes that the term taqiyya does not occur even once with the technical meaning "dissimulation" in the many polemic documents that he examined for his work. ${ }^{11}$ To

${ }^{7}$ Harvey, Muslims in Spain, p. 60.

${ }^{8}$ Dressendörfer, Islam unter der Inquisition: Die Morisco-Prozesse in Toledo 15751610, pp. 131-52.

9 Harvey, "Una referencia explícita", p. 561.

${ }^{10}$ García-Arenal, Inquisición y Moriscos, pp. 101-02.

${ }^{11}$ He asks, “(...) le peuple morisque, dans sa vie quotidienne, et les polémistes, dans leur écrits, avaient-ils conscience d'appliquer ce principe islamique, ou agissaient-ils et écrivaient-ils en réagissant spontanément aux circonstances que se présentaient à eux?", Cardaillac, Morisques et Chrétiens, p. 99. 
what extent were educated or uneducated Moriscos aware of Islamic doctrinal justifications for the practice of dissimulation, and to what extent was the Morisco's behavior guided by theoretical injunctions contained in Islamic legal or other literature? ${ }^{12}$ Harvey remarks that the need for a discussion of taqiyya has been felt for some time. ${ }^{13}$

Widely cited as endorsing the Moriscos' resort to taqiyya is a fatwa issued in 910/1504 by the North African jurist Abū l- ${ }^{-A b b a ̄ s ~ A h ̣ m a d ~ b . ~}$ Abī Jum a al-Maghrāwī al-Wahrānī (d. 917/1511). This legal responsum provides comprehensive dispensation to Moriscos to feign adherence to Christianity, allowing them to perform acts that are ordinarily forbidden or omit acts that are ordinarily obligatory as long as they internally reject their outward acts and understand that the underlying prohibitions and obligations still hold. Many ordinary Islamic legal stipulations are suspended: the Moriscos may drink wine or eat pork if forced; they may pray with the Christians, utter blasphemous Christian creeds, or insult the Prophet Muhammad if they are compelled to do so; they may dispense with the ordinary obligations connected with ritual ablutions and prayer if circumstances require; they may even marry their daughters to Christians if coerced, as long as they retain the conviction that this is ordinarily forbidden. Harvey calls this fatw $\bar{a}$ "the key theological document for the study of Spanish Islam" in the period following the Reconquista and leading up to the expulsions. ${ }^{14}$ Particularly since Harvey's 1964 article, this fatw $\bar{a}$ has been addressed in many studies on the history of the Moriscos and the status of Muslim minorities under non-Muslim rule. ${ }^{15}$

12 Cardaillac, "Un aspecto de las relaciones," pp. 107-22. 184-85.

3 Harvey, "Una referencia explícita", p. 562; also Harvey, Muslims in Spain, pp.

14 Harvey, Muslims in Spain, p. 60.

15 Harvey, "Crypto-Islam"; Cardaillac, Morisques et Chrétiens, pp. 88-90; Cardaillac, "Un aspecto de las relaciones," pp. 108-10; Vernet, "La Exégesis Musulmana”, p. 125; Sabbagh, "La religion des Moriscos entre deux fatwas", pp. 49-55; Chejne, Islam and the West, p. 24; Epalza, "L'identité onomastique et linguistique des Morisques"; Bouzineb, "Respuestas de jurisconsultos magrebíes en torno de la inmigración de musulmanes hispánicos", pp. 53-54, 59-60; Razūq, al-Andalusiyyūn wa-hijrātuhum ilā al-Maghrib khilāl al-qarnayn 16-17, pp. 150-51; Fierro, "La emigración en el Islam: conceptos antiguos, nuevos problemas", pp. 21-22; Harvey, "The Political, Social and Cultural History", pp. 209-10; Abou El Fadl, "Islamic Law and Muslim Minorities: The Juristic Discourse on Muslim Minorities from the Second/Eighth to the Eleventh/Seventeenth Centuries", esp. pp. 156-57, 179-80; Epalza, "La voz oficial de los musulmanes hispanos, mudéjares y moriscos, a sus autoridades cristianas: cuatro textos, en árabe, en castellano y en catalán-valenciano", pp. 290-95; Molénat, "Le problème de la permanence des musulmans dans les 
While many have viewed al-Wahrānī's fatwā as legitimating the use of taqiyya by Moriscos, others have disagreed. Sabbagh notes that taqiyya is most important for Islamic sectarian groups, including the Shīites and the Khārijis, particularly the Ibāḍi Khāriji sect. Sunnis do not favor the concept, she claims, since it is a dangerous principle for the moral life of the community and weakens notions of jiha $\bar{d}$ and martyrdom. ${ }^{16}$ Molénat notes that although the fatwa $\bar{a}$ provides all the means for practicing "crypto-Islam", Ibn Abì Jum'a does not present theoretical justification and does not use the term taqiyya itself. ${ }^{17}$ Rubiera Mata concurs, adding that al-Wahrānī's fatwā is an anomaly among other fat$w \bar{a}$ s from Iberia and North Africa addressing the status of Muslims living under Christian political domination; taqiyya in her view is a Shī ite concept that the Sunni Moriscos would have neither recognized nor used. ${ }^{18}$

A number of statements from Spanish authors in the sixteenth and seventeenth centuries refer to the Islamic legal dispensation more or less directly, though without using the term taqiyya, suggesting that at least some of the Moriscos and their interlocutors must have been familiar with the concept. The inhabitants of the Muslim town of María, near Zaragoza, rose in rebellion following the forcible conversion of the Muslims of Aragon in 1526. The besieged rebels agreed to surrender only after a Christian noble informed them that they were permitted by their own religion to dissimulate:

Sad and unfortunate people, who in this manner will deliver yourselves into the hands of your enemies! If you refuse to be baptised in order not to go against your Qur'ān, then learn something that is permitted to you therein: show yourselves to be Christians and get baptised, while keeping your heart for Muhammad. You will thereby be delivered from the present danger, if you are forced to surrender by arms, and from future dangers as you roam as fugitives the world. ${ }^{19}$

territoires conquis par les Chrétiens, du point de vue de la loi islamique", pp. 399-400; Pormann, "Das Fatwa Die Herrlichsten Waren (Asnā l-matāğir des al-Wanšarìsì)", pp. 311-12; Rubiera Mata, "Los moriscos como criptomusulmanes y la Taqiyya"; Harvey, Muslims in Spain, pp. 60-64.

${ }^{16}$ Sabbagh, "La Religion des Morisques", pp. 53-55.

${ }_{17}$ Molénat, "Le Problème de la permanence", pp. 399-400.

18 "La taqiyya es un concepto de los chiíes, la más importante secta del Islam, para disfrazar su pertenencia a ella, es decir, que son chí́es en el ámbito sunní, pero jamás para simular que no son musulmanes. Es decir, que el escrito de Al-Magrawi va mucho más allá de la taqiyya, doctrina que además, seguramente como sunní no conocía”, Rubiera Mata, "Los moriscos como criptomusulmanes", p. 547.

${ }^{19}$ Guadalajara y Xavier, Memorable expulsión y justísimo destierro de los Moriscos de España, fol. 51v; Harvey, “Crypto-Islam”, pp. 170-71. 
Here, the Christian noble alludes to a specific dispensation recorded in the text of the Qur'àn; the text reads: ... que os es permitido en él, "... that is permitted to you in it", referring to Islam's holy book..$^{20}$ This may be a reference to Q 16:106, which is discussed below. Guadalajara y Xavier refers to the Islamic doctrinal support for dissimulation when he writes of the difficulty of converting Moriscos into true Catholics:

I only wish to state, by the way, that, with the permission and licence that their accursed sect accorded them, they could feign any religion outwardly and without sinning, as long as they kept their hearts nevertheless devoted to their false imposter of a prophet. We saw so many of them who died while worshipping the Cross and speaking well of our Catholic Religion yet who were inwardly excellent Muslims. ${ }^{21}$

The juxtaposition of the terms permiso "permission" and licencia "license" with ocasiones forçosas "coercive circumstances" suggests a direct reference to the Islamic legal dispensation of $i k r a \bar{h}$, "coercion, duress", which resembles taqiyya in many aspects and may be connected as well with Q 16:106.

At least one indication that the Moriscos themselves were aware of the specific term taqiyya has been presented in scholarship to date: Harvey has identified a passage of a sixteenth-century aljamiado text by Mancebo de Arévalo that provides an explicit reference to taqiyya, rendered in Spanish vernacular as amonestança. ${ }^{22}$ Additional evidence regarding taqiyya from Sunni legal and other sources that would have been available in Spain and North Africa during the time of the Moriscos and in the preceding centuries will be presented below.

The situation of the Moriscos was not entirely unprecedented in Islamic history, and Sunni Muslims had invoked taqiyya to justify dissimulation under Christian domination in other periods and regions, including Sicily after the Norman conquest in 1061-91 and the Byzantine Marches in eastern Anatolia, northern Syria, and northern Iraq during the early Islamic centuries. Border wars with Byzantium began very soon after the initial expansion of the Islamic Empire in the seventh century and remained a constant aspect of the political and military

${ }^{20}$ Harvey's translation elides the text here: “... you should be informed that you are permitted to put on a show of being Christians ...", Harvey, "Crypto-Islam", p. 170.

${ }^{21}$ Guadalajara, Memorable expulsión, fol. 159; Cardaillac, Morisques et Chrétiens, p. 99.

${ }^{22}$ Harvey, "Una referencia explícita", p. 562; also Harvey, Muslims in Spain, pp. 184-85. 
history of Islamdom until the Crusader conquests and the establishment of the Frankish states of Outremer changed the parameters of that conflict at the close of the eleventh century. The Byzantine Crusade, led in the mid-tenth century by the general-emperors Nicephorus II Phocas (963-69) and John Tzimisces (969-76), resulted in the annexation of large territories that had been under Muslim rule in Crete, Cilicia, and northern Syria, including the major cities of Tarsus, Missisa, and Adana, conquered in 964-66, and Antioch, conquered in 969. As a consequence, large Muslim populations came under Christian rule and faced difficult questions regarding religious status, religious and cultural identity, discrimination, and conversion.

Sources reveal that some Sunni Muslim captives in the hands of the Byzantines dissimulated in conscious accordance with the Islamic legal dispensation of taqiyya. In the late tenth century, Mutazili theologian al-Qāḍi 'Abd al-Jabbār (d. 415/1025) criticized the morals of Byzantine Christians, suggesting, among other things, that they did not consider marital infidelity on the part of their wives a serious infraction. In order to prove this, he relates an account of a Muslim warrior who had fallen captive, feigned conversion to Christianity, and married a well-to-do Christian woman. Later, when he was sent by the Emperor on a military mission, he heard that his wife had taken a lover, but when he confronted her relatives about this, they assured him that it was quite ordinary for a woman in her position to do this, adding that it was advantageous for him, as the lover assumed responsibility for the expenses of the family and property in his absence. Even if this is not an accurate portrayal of the mores of Byzantine matrons, the account proves that the Muslim warrior dissimulated, feigning conversion to Christianity. In addition, he was not alone in his dissimulation:

\footnotetext{
... Muṣbih al-Ṭā'̄î, Abū 'Abd Allāh al-Ḥusayn b. al-Ṣaqr, 'Abd al-Raḥmān the warrior under Ibn al-Zayyāt, and other border warriors and those who resided many years in Constantinople, both as captives and as free men, (...) because of the long hardship they suffered and because the Muslims did not send anyone to ransom them or to fight the enemy, feigned conversion to Christianity out of dissimulation and spread out among the Christians and mixed with them. ${ }^{23}$
}

${ }^{23}$ Al-Qāḍi 'Abd al-Jabbār, Tathbīt dalā'il al-nubuwwa, pp. 171-72; Abū Ja'far Muhammad b. 'Abd al-Malik al-Zayyāt served as vizier from 836 A.D. on, under alMu'tașim (r. 833-42), al-Wāthiq (842-47), and al-Mutawakkil (r. 847-51). 
Al-Qādị al-Jabbār's description of their conversion, "they outwardly adopted Christianity out of dissimulation" (azharū l-nașrāniyata taqiyyatan), uses the explicit term taqiyya to denote their outward conformance to Christianity. It also assumes that they were aware of the concept of taqiyya as an Islamic legal dispensation available to them on account of their circumstances.

\section{The 910/1504 Fatwā of Aḥmad Ibn Abì Jumª}

Abū l-'Abbās Aḥmad Ibn Abī Jum a al-Maghrāwī al-Wahrānī (d. 917/1511), a Mālikí jurist who completed his studies in Tlemcen and spent his later career as a professor in Fez, wrote his responsum for the Moriscos in 910/1504, probably in Fez. ${ }^{24}$ The fatwa does not mention earlier fatwās, court cases, or legal discussions of the particular topic addressed, so it is difficult to determine the exact provenance of its ideas and its place in historical legal debates. Nevertheless, attention to Islamic legal literature allows a better understanding of the reasoning

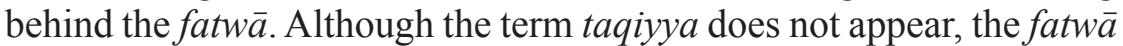
includes several related technical legal and theological terms, including niyya "intention", ikrāh "coercion, duress", and kalimat al-kufr "blasphemy", and alludes as well to Qur'ānic verses and hadìth reports that belong to the standard repertory of scriptural proof-texts used to legitimate taqiyya.

${ }^{24}$ On this scholar, see Stewart, "The identity of 'the Mufti of Oran': Abū al 'Abbas Aḥmad b. Abī Jum 'a al-Maghrāwī al-Wahrānī (d. 917/1511)". L.P. Harvey published photographic plates of the vatican ms. of the fatwa and discussed the text in his 1958 doctoral dissertation on aljamiado literature, and his complete transcription of that manuscript appeared in the proceedings of a conference on Arabic and Islamic studies held in Cordoba in 1962, together with photographic plates of the manuscript folios and a summary of its provisions in English; Harvey, The Literary Culture of the Moriscos (1492-1609): A Study Based on the Extant Manuscripts in Arabic and Aljamia. The discussion is given at vol. I, 175, pp. 293-300 and the plates of the manuscript in Appendix C: vol. 2, pp. 184-88; Harvey, "Crypto-Islam." In 1971, Dressendörfer provided a nearly complete German translation in Islam unter der Inquisition, pp. 137-41; Leila Sabbagh commented on the available translations in 1983, making some valuable points, but did not translate the fatwa ; Sabbagh, "La religion des Moriscos", pp. 49-55. Rubiera Mata provided a near-complete Spanish translation of V in 2004, Rubiera, "Los Moriscos como criptomusulmanes", pp. 541-44. Harvey's 2005 book on the Moriscos includes an English translation of the text, also nearly complete: Harvey, Muslims in Spain, pp. 24, 61-63. 


\section{Taqiyya in Sunni Islam}

Taqiyya, literally "fear, caution" is an Islamic legal dispensation (rukhṣa) allowing dissimulation in cases of danger. It permits a legally responsible believer to perform certain acts under duress that would ordinarily be forbidden or to omit certain acts that would ordinarily be obligatory. Taqiyya is emblematic for the posture of a persecuted and necessarily secretive minority. Investigators of the history and religion of the Moriscos have shown little awareness that a small but growing corpus of secondary literature on taqiyya exists, much less plumbed Islamic sources for discussions of taqiyya. ${ }^{25}$

A major hindrance to the investigation of taqiyya in the context of Moriscos or Muslims in Spain has been the widespread and erroneous belief that the concept and practice of taqiyya are the exclusive domain of Twelver Shī ites and other Muslim sectarian minorities and are not relevant to Sunni Islam. Shīites have practiced taqiyya more widely than Sunnis and cite the concept more frequently in their literature and daily lives for the obvious historical reason that, throughout most of Islamic history and in most regions, they have lived as a minority under Sunni rule, surrounded by a potentially hostile majority. Yet while historical realities have conspired to make taqiyya appear to be an exclusively Shi ite principle, the option of taqiyya was doctrinally available to Sunnis, and Goldziher pointed out long ago that taqiyya is an accepted principle in Sunni as well as Shīeite Islam. Even so, alleged overuse of taqiyya became a standard part of Sunni polemics against the Shi ites. Ibn Taymiyya (d. 728/1328), for example, denounces the ráfida "rejectors"-the common term of opprobrium for Shi' ites among medieval Sunnis- as through-and-through hypocrites because of their

${ }^{25}$ On taqiyya see Goldziher, "Das Prinzip der takijja im Islam"; Strothmann, "Takiyya"; Meyer, "Anlass und Anwendungsbereich der taqiyya"; Kohlberg, "Some Imāmī-Shīê Views on Taqiyya"; Kohlberg, "Taqiyya in Shīề Theology and Religion"; Gordon, "The Substratum of Taqiyya in Iran"; Dupree, "Further Notes on Taqiyya: Afghanistan"; Fawzī, Mafhūm al-taqiyya fi l-Islām; Layish, "Taqiyya among the Druzes"; Stewart, "Taqiyyah as Performance: The Travels of Bahā' al-Dīn al- 'Amilī in the Ottoman Empire (991-93/1583-85)"; Stewart, "Husayn b. 'Abd al-Samad al- Āmilī's Treatise for Sultan Suleiman and the Shī î̀-Shāfî̀ Legal Tradition"; Stewart, Islamic Legal Orthodoxy: Twelver Shiite Reactions to the Sunni Legal System; Stewart, "Documents and Dissimulation: Notes on the Performance of Taqiyya"; Makārim, al-Taqiyya fi l-Islām; Clarke, "The Rise and Decline of Taqiyya in Twelver Shi ism"; Dakake, "Hiding in Plain Sight: The Practical and Doctrinal Significance of Secrecy in Shi ite Islam". 
constant practice of taqiyya. ${ }^{26}$ A sixteenth century Iranian Sunni scholar identifies the acceptance of taqiyya as one of the Shi' ites' gravest sins and blames them for applying it to a shocking extent, so that it affects nearly all Islamic legal injunctions. ${ }^{27}$ Sunni Muslims have often likened Shīites, on account of their resort to taqiyya, to the Munāfiqūn "Hypocrites", a group decried in the Qur'ān as outward Muslims who are secretly unsympathetic to the cause of Muslims and actively seek to undermine the Muslim community. ${ }^{28}$

Because of these polemic connotations, the term taqiyya is often avoided in Sunni discussions of doctrine, despite the fact that it occurs explicitly in fundamental texts in the Sunni tradition, including canonical hadith collections, well-known commentaries on the Qur'ān, and other works. The relative infrequency of the term, however, does not indicate a lack of attention to the topic or a rejection of the concept. Sunni legal discussions of $i k r a \bar{h}$ "coercion, duress" regularly cover the same topics that Shī ites discuss under the rubric of taqiyya, using similar terms and examples and many of the same scriptural prooftexts, in works that would have been well known to Andalusian and North African Mālikī jurists. Khaled Abou El-Fadl recognizes that Ibn Abī Jum 'a's fatwa is is based on the concept of duress or coercion (ikrāh) ${ }^{29}$ Some Islamic legal works devote a separate chapter to the topic, as is the case with al-Marghinānī's (d. 593/1197) Hidāya, one of the most popular texts of Hanafi law. ${ }^{30}$ Others discuss duress in various contexts, such as the chapter on judgeship. In addition, many Sunni texts discuss taqiyya explicitly and in some detail.

The principle of taqiyya is based on the idea prevalent in Sunni as well as Shì ite law and theology that inner convictions potentially differ from manifest statements and actions and that one ought to be judged

${ }^{26}$ Ibn Taymiyya, Minhāj al-sunna, vol. 2, pp. 29-32.

${ }^{27}$ Makhdūm al-Shīrāzī, al-Nawāqid fì l-radd 'alā al-rawāfid, fols. 67-68.

28 Adang, "Hypocrites and Hypocrisy."

29 Abou El-Fadl, "Islamic Law", p. 179. For an overview of duress in Islamic law, see Abou El-Fadl, "The Common and Islamic Law of Duress"; Abū Șafiya, al-Ikrāh fì lsharīa al-Islāmiyya; al-Husaynī, al-Ikrāh wa-atharuh fì l-ahkām àl-shar'iyya: dirāsa muqārana qū'ima 'alà al-istiqșā' li-l-furū' al-'aqā'idiyya wa-l-fiqhiyya; Abdur Rahim, The Principles of Muhammadan Jurisprudence: according to the Hanafi, Maliki, Shafi'i and Hanbali Schools.

${ }^{30}$ Burhān al-Dīn Abū l-Ḥasan 'Alī b. Abī Bakr al-Farghānī al-Marghīnānī, al-Hidāya sharh Bidāyat al-mubtadī; English translation, section on "compulsion", in The Hedaya, or Guide: A Commentary on the Mussulman Laws. 
on the basis of the former. Intention (niyya) is a fundamental concept in Sunni Islamic law. ${ }^{31}$ Without it, the performance $\left(a d \bar{a}^{\prime}\right)$ of legal obligations is invalid; the mere completion of an act does not suffice. All practicing believers should know the concept, since daily prayer is invalid if performed without forming one's intention to direct the prayer to God alone. Perhaps the best known of all Prophetic hadith reports is innamā l-a'mālu bi-l-niyyāt "works are (judged) according to intentions", which appears as the very first hadìth in the Sahìh of al-Bukhārī (d. 256/870) and in al-Nawawi's (d. 676/1277) popular collection of forty hadìths. As al-Tūfì (d. 716/1316), one of the many commentators on al-Nawawì's work, explains, this dictum has profound legal implications. For example, a man who has sexual intercourse with a woman whom he believes to be his wife is not subject to the penalty for adultery. Similarly, a Muslim who drinks alcohol without realizing or intending to do so is not subject to any penalty. ${ }^{32}$ In Islamic theology generally, one's conviction ( $\left.i^{\prime} t i q \bar{a} d\right)$, located in the heart (qalb), is often contrasted with one's word ( $q a w l)$, made by the tongue (lisān), and deed $\left(f{ }^{\prime} l\right)$, performed by the hand (yad) or limbs (jawärih). The distinction between an external, obvious, or prima facie meaning (zāhir) that can differ quite radically from an internal or hidden meaning (ba tatin) is also ubiquitous in Islamic literature and thought. Ibn Abi Jum 'a's fatwā stresses that it is not one's outer actions that make one a Muslim, but one's inner state or intention. God is more concerned with believers' intentions than their outward acts. Paraphrasing another well-known hadìth report, he states, Allāhu lā yanzuru ilā șuwarikum lākin ilā quīübikum "God does not look at your external forms but rather at your hearts". One's beliefs or opinions about the law make one a Muslim and not one's success in applying its specific dictates. The essence of belief is therefore not adherence to the law per se, but in holding the correct opinions about it. Al-Ghazālì (d. 505/1111) discusses intention at some length in his famous work Ihy $\bar{a}$ ' 'ulüm al-dìn, citing a number of hadìth reports, including innamā l-a'mālu bi-lniyyāt li-kulli mri'in ma nawā... "Actions are judged only according to intentions. For each man is what he intends..." and also inna llāha ta 'ālà lā yanzuru ilā șuwarikum wa-amwālikum wa-innamā yanẓuru

31 Sabbagh, "La religion des Morisques", pp. 54-55.

32 Sulaymān b. 'Abd al-Qawī al-Ṭūfî, Kitāb al-ta 'yīn fì sharh al-Arba 'ìn, pp. 36-37. 
ilā qulūbikum wa-a'mālikum "Exalted God does not look at your external forms and your belongings but rather looks exclusively at your hearts and your works". ${ }^{33}$

The concept of taqiyya is discussed in many Sunni sources that would have been available, either directly or indirectly, to religious scholars and literate Muslims of al-Andalus and North Africa before, during, and after the Reconquista. The main categories of such texts are Qur'ānic commentaries, hadìth collections and associated compendia and commentaries, legal manuals, and works on Islamic theology and ethics such as al-Ghazālī's Ihy $\bar{a}$ ' 'ulüm al-dīn. The Qur'ānic verses at which commentaries regularly discuss taqiyya or closely related matters are three: Q 3:28, which uses the cognate terms ittaq $\bar{u}$ and $t u q \bar{a} h$ or taqiyya and refers to dissimulation; Q 16:106, which assesses the status of a believer who blasphemes under coercion; and Q 40:28, which depicts a relative of Pharaoh who was a true believer but concealed the fact. In her investigation of aljamiado translations of the Qur'ān, Consuelo López-Morillas provides a picture of the tradition of tafsir that provided the background for the Moriscos' interpretation of the text. She identifies four Eastern and four Western commentaries as fundamental: from the East, Jāmi' al-bayān by al-Ṭabarī (d. 310/923), al-Kashshāf by al-Zamakhsharī (d. 528/1135), Mafâtīh al-Ghayb by Fakhr al-Dīn al-Rāzì (d. 606/1209), and Anwār al-tanzīl by al-Bayḍāwī (d. 685/1286), and from the West, Tafsìr al-Qur'ān by Ibn Abì Zamanīn (d. 399/1008), al-Muharrar al-wajiz fi tafsìr al-Kitāb al-'Azìz by Ibn 'Ațiyya al-Gharnāțī (d. 546/1151), al-Jāmi' li-aḥkām al-Qur'ān by alQurțubī (d. 671/1273), and al-Bahr al-muhìt fi tafsìr al-Qur'ān by Abū Hayyān al-Gharnātịi (d. 745/1344). Of these, she notes that Ibn Abī Zamanin's Tafsīr is preserved in truncated form in an aljamiado MS. Especially influential for the Moriscos were the commentaries of al-Zamakhsharī and Ibn 'Ațiyya al-Gharnātị. Aljamiado translations of the Qur'ān also incorporated material from tafsìr sources without acknowledgement. López-Morillas suspects that the aljamiado writer 'īsā b. Jābir (Ice de Gebir) consulted a wide variety of tafsìr works and incorporated material from them in his influential but now-lost aljamiado translation of the Qur'ān, which he completed in 1456. Later aljamiado translators or copyists of Qur'ān translations may have drawn exten-

33 Al-Ghazālī, Ihyāa' 'ulūm al-dìn, vol. 5, pp. 1741-57. 
sively on 'Īsā b. Jābir's work and thus passed on commentary and interpretation of the text without independent access to works of tafsis.$^{34}$ Several hadiths that appear in the standard Sunni collections such as al-Bukhārì's Șahịh discuss the use of verbal ambiguities as a means to escape harm or persecution. Legal manuals discuss matters related to taqiyya under the topics of coercion, the duty to enjoin good and denounce wrong in public, legal stratagems, and affidavits of pre-emption (istir ' $\bar{a}$ '). Since many Qur'ānic commentaries and hadith works discuss legal matters, and since Qur'ānic commentaries and legal manuals often cite hadith reports as evidence, the categories overlap.

The term taqiyya likely derives from Q 3:28, which is widely held to justify dissimulation in front of potential enemies. The verse reads, "Let not the believers take unbelievers for their allies in preference to believers. Whoever does this has no connection with God, unless you but guard yourselves against them as a precaution (illa an tattaqū minhum tuqātan/taqiyyatan). God bids you beware only of Himself..." AlTabarī, al-Zamakhsharī, al-Bayḍāwī, and others report the recognized variant reading taqiyyatan, a verbal noun construed as a cognate accusative ("the act of being cautious"), rather than tuqātan, a plural adjective construed as an accusative of condition ("while you are exercising caution"). Whether the actual term taqiyya or its cognate tuqāh occurs in this verse, there is little doubt that the cognate verb ittaq $\bar{a}$ refers to dissimulation, so that, one may claim, both the term and the concept of taqiyya are based on an explicit Qur'ānic text. Most Sunni tafsīrs use the term taqiyya in explicating the verse. ${ }^{35}$

Nonetheless, the scriptural text by which taqiyya is most often justified is Q 16:106: "Whoever expresses disbelief in God after having accepted belief [will suffer greatly]-except him who is forced while his heart is still at peace in belief'. This verse is also the locus classicus for the legal topic of coercion ( $i k r \bar{a} h)$, particularly since the cognate

${ }^{34}$ López-Morillas, The Qur'ān in Sixteenth-Century Spain: Six Morisco Versions of Süra 79. Vincent Cornell has called attention to the exegeses of Ibn 'Ațiyya and al-Qurtubi in particular as prominent representatives of the Andalusian tradition of Qur'ān commentary. Cornell, "'Ilm al-Qur'ān in al-Andalus: The Tafsìr Muharrar in the Works of Three Authors".

${ }_{35}$ Al-Ṭabarī, Jāmi' al-bayān 'an wujūh ta'wìl ày al-Qur'ān, vol. 3, pp. 227-30; al-Zamakhsharī, al-Kashshāf 'an haqā'iq al-tanzīl, vol. 1, p. 183; al-Rāzī, Mafătīh al-ghayb [alTafsīr al-kabìr], vol. 8, pp. 10-14; al-Bayḍāwī, Anwāar al-tanzīl, pp. 70-71; al-Jașșāṣ, Ahkām al-Qur'ān, vol. 2, pp. 289-90; al-Qurțubì, al-Jāmi' li-ahkām al-Qur'ān, vol. 4, p. 57. 
ukriha "was forced, coerced" occurs in it. It is said to refer to the case of the Companion 'Ammār b. Yāsir, who was compelled by polytheists in Mecca to worship pagan idols and deny the Prophet Muhammad. His parents, Yāsir and Sumayya, were brutally killed for refusing, but 'Ammār succumbed to their demands and thus survived. Afterwards, when he confessed to the Prophet what had happened, the Prophet asked him how he felt in his heart, and 'Ammār responded that his heart "was at ease in belief". The Prophet informed him that this was all that was necessary, and if the polytheists were to attack him in a similar fashion in the future, he should repeat his actions. A second account that frequently occurs in commentaries on this verse relates that Musaylima, the false prophet of the Banu Hārith who was contemporary with the Prophet Muhammad, demanded that two Muslim captives recognize him as a legitimate messenger of God along with Muhammad. One prisoner acquiesced, but the other did not answer, feigning deafness, and was killed as a result. When informed about the incident, the Prophet Muhammad legitimated the actions of both prisoners, stating that one was allowed to dissimulate if one's life was in danger, but that one was also free to choose the path of martyrdom. These accounts occur in nearly all the well-known Sunni exegeses, including popular Mālikī commentaries such as al-Qurțubī's (d. 671/1272-73) al-Jāmi' li-ahkām al-Qur'ān. ${ }^{36}$ The key phrase wa-qalbuhu muțma'inn bi-l-ìmān "while his heart is still at peace in belief" appears in many Sunni legal discussions of both taqiyya and coercion and, noticeably, in Ibn Abi Jum 'a's fatwā.

Sūrat al-Mu'min depicts an actual performance of religious dissimulation in the course of a confrontation between Moses and Pharaoh (Q 40:22-54). When Pharaoh threatens to kill Moses (v. 26), an Egyptian described as a member of Pharaoh's family who concealed his faith (rajulun mu'minun min āli Fir'awna yaktumu ìmānahu) (v. 28) speaks up in Moses' defense. Some commentators claim he was a Hebrew, assigning him the name Sam ‘ān, Sham ān, Ḥabīb, Ḥizqīl, Hizbīl, or

${ }^{36}$ Al-Ṭabarī, Jāmi al-bayān, vol. 14, pp. 180-82; al-Zamakhsharī, al-Kashshāf, vol. 2, p. 345; al-Rāzī, Mafâtīh al-ghayb, vol. 20, p. 121; al-Jașșāṣ, Ahkām al-Qur'ān, vol. 5, pp. 13-17; al-Bayḍāwī, Anwār al-tanzìl, p. 367; al-Qurțubī, al-Jāmi' li-ahkām al-Qur'ān, vol. 10, pp. 180-81; Ibn Kathīr, Tafsìr al-Qur'ān al- 'azìm, vol. 2, p. 609; al-Kalbī, Kitāb al-tashīl li- 'ulüm al-tanzìl, vol. 2, pp. 162-63. See also Friedmann, Tolerance and Coercion in Islam: Interfaith Relations in the Muslim Tradition, pp. 153-56. 
Khirbil, but most consider him Egyptian, for several reasons: the Hebrew interpretation assumes inverted word order without sufficient grounds; the preposition min is not usually used with the verb yaktumu, which would ordinarily take two direct objects; a Hebrew would not likely have confronted Pharaoh in this manner; and Pharaoh would have reacted more harshly to a Hebrew. In addition, some commentators identify him as Pharaoh's paternal cousin, heir apparent, or trusted advisor. ${ }^{37}$ This believing member of Pharaoh's family is thus a counterpart to Nicodemus in the New Testament, a highly placed individual who hid his belief out of prudence. Given the salience of this passage in the Qur'ān, it is difficult to claim that Sunni Muslims would be unaware of the concept of dissimulation; it is presumably because of this passage that the term kitmān "concealment" comes to be used as an occasional synonym of taqiyya in Islamic legal literature.

\section{Fakhr al-Dīn al-Rāzī on Taqiyya}

One Sunni commentator who provides a substantial discussion of dissimulation is Fakhr al-Dīn al-Rāzì (d. 606/1209) in his voluminous exegesis Mafätīh al-ghayb. This analysis forms one section of his commentary on Q 3:28.

Know that taqiyya has many rulings associated with it; we will mention some of them.

The first ruling: taqiyya occurs when a man is among a large group of unbelievers, fears for his life or property from them, and beguiles or cajoles them with his tongue. He does this by avoiding disclosure of enmity with his tongue. It is also permissible to produce speech that gives the impression of friendship and alliance but on condition that he internally maintain (yudmir) the opposite and use allusive language (yu'arrid) in all of what he says, for taqiyya affects what is externally apparent and not what is in people's hearts.

The second ruling regarding taqiyya is that if the believer declares his faith and the truth outright in a case where he is allowed to perform taqiyya, then that is more meritorious. The proof of this is what we have stated above regarding the story of Musaylima.

The third ruling: taqiyya is only permissible regarding that which is related to dis-

37 Al-Tha labī, al-Kashf wa-l-bayān, vol. 8, pp. 272-73; al-Zamakhsharī, al-Kashshāf, vol. 3, p. 367; Ibn 'Ațiyya al-Andalusī, al-Muharrar al-wajìz fì tafsīr al-Kitāb al- 'azīz, vol. 4 , p. 552 
playing alliance and enmity, and perhaps also regarding that which is related to disclosing one's religion. However, acts which result in harm to others, such as murder, adultery, usurpation of property, taking false witness, accusing married women of adultery, and revealing vulnerabilities of the Muslims' defenses to the unbelievers, are not at all permissible.

The fourth ruling: The obvious sense of the Qur'ānic verse indicates that taqiyya is allowed before unbelievers who are dominant. However, the opinion of al-Shāfi ${ }^{1} \overline{1}$ (may God be pleased with him) is that when the situation among Muslims resembles that which obtains between Muslims and polytheists, then taqiyya becomes legal as a means to protect life.

The fifth ruling: taqiyya is permissible for the purpose of preservation of life. Is it also permissible for the preservation of property? One should probably rule in favor of permissibility in this case, because of the statements of the Prophet (may God bless him and grant him peace), "The inviolability of a Muslim's property is like the inviolability of his life" and "He who is killed protecting his property is a martyr". [It should also be permissible] because man has a compelling need of property. For example, when water is sold for an exorbitant price, the obligation to perform ablution no longer holds, and one is permitted to make do with tayammum in order to avoid decreasing one's wealth by that amount. How, then, could it not be permissible here?

The sixth ruling: Mujāhid [b. Jabr, d. 104/722] said, "This ruling held sway in the beginning of Islam because of the weakness of the believers. However, since Islamic rule has grown strong, it no longer holds". But 'Awf [b. Abī Jamīla, d. 146/763] related on the authority of al-Hasan [al-Bașrī, d. 110/728], "Taqiyya is permissible for the believers until the Day of Resurrection". This last view is more reasonable, because it is obligatory to prevent harm to one's person as far as possible. ${ }^{38}$

Al-Rāzī accepts taqiyya as a general principle of dissimulation in Sunni Islamic law. He rejects Mujāhid's opinion that taqiyya has been suspended because the Islamic state is no longer weak, and he endorses the statement attributed to al-Hasan al-Bașrī according to which taqiyya will be permissible until the Day of Resurrection. In his view, dissimulation may be applied to both word and deed. One may resort to it in order to protect both life and property. A Muslim may dissimulate not only among unbelievers but also among other Muslims. It has limits, and one may not resort to it when it would cause harm to others or their property.

38 Al-Rāzī, Mafâtīh al-ghayb, vol. 8, p. 13. 


\section{Ibn Abì Zamanīn's Tafsìr}

One of the exegeses most frequently cited in al-Andalus was the Tafsìr of Ibn Abì Zamanīn, which he abridged from the work of Yahyā b. Sallām al-Tamīmī al-Bașrī (d. 200/815) and completed in Sha bān 395/May-June 1005 in Cordoba. ${ }^{39}$ As part of the commentary on Q 3:28, he includes the following account of the dissimulation of ${ }^{\circ}$ Ammār b. Yāsir, the Companion of the Prophet who was forced to worship the pagan gods in Mecca.

...Muhammad b. 'Ammār b. Yāsir ... stated: The polytheists took my father, and they did not leave off from him until he insulted the Messenger of God (may God bless him and grant him peace) and spoke well of their gods, and then they let him go. When he came to the Prophet (may God bless him and grant him peace), the Prophet asked him, "What befell you?" 'Ammar replied, "Evil, O Messenger of God. By God, I was not let go until I insulted you and spoke well of their gods." The Prophet asked, "How did you find your heart?" He answered, "I find it at peace in faith". He said, "If they do it again, then you do it again". 40

In another passage, Ibn Abī Zamanīn again cites the phrase "except for him who is forced while his heart is at peace in faith" in connection with the dissimulation of 'Ammār $b$. Yāsir before a pagan audience:

"Whoever denies God after accepting faith, except for him who is forced while his heart is at peace in faith"-that is, accepts it. This was revealed concerning 'Ammār b. Yāsir and his Companions. The polytheists had seized them and forced them to denounce God and His Messenger. Because of their fear of them, they gave them that with their mouths [alone]. ${ }^{41}$

Ibn Abī Zamanīn does not use the technical term taqiyya but describes the concept and cites the historical anecdote most commonly held to legitimate the practice.

\section{Ibn 'Aṭiyya al-Gharnāțī (d. ca. 546/1151) on Taqiyya and Ikrāh}

The Andalusian jurist Ibn 'Atiyya (d. ca. 541/1147) discusses taqiyya in his popular exegesis al-Muharrar al-wajiz, one of the most widely

${ }^{39}$ Ibn Abī Zamanīn, Tafsìr, vol. 1, p. 9.

40 Ibn Abì Zamanīn, Tafsìr, vol. 1, p. 108.

${ }^{41}$ Ibn Abì Zamanīn, Tafsìr, vol. 1, p. 446. 
renowned in the Māliki tradition. ${ }^{42}$ His commentary on Q 3:28 reports that scholars' opinions have differed regarding three relevant legal questions: before whom may one perform taqiyya, under what circumstances is taqiyya permissible, and what acts are permitted under the dispensation of taqiyya? The interlocutor before whom one may perform taqiyya is defined as: "Any powerful person who exercises hegemony, who causes duress, and whom one fears. This includes unbelievers when they hold the reins of power, tyrannical leaders and usurpers, and people of high station in the great cities". According to Mālik (d. 179/795), even a woman's husband might place her under duress, such that it would be lawful for her to exercise taqiyya before him. The circumstances under which taqiyya is allowed are the following:

\begin{abstract}
... fear of death, fear of loss of limb, flogging and other types of torture. If a person is subjected to any of these or harbors a deep-seated fear that he will be subjected to them, then he is under duress, and the status of taqiyya applies to him. Imprisonment constitutes duress, as do shackling, threatening, and menacing. Enmity on the part of tyrannical people of high station permits taqiyya. All these vary according to the condition of the person placed under duress and the act forced upon him. For many, imprisonment does not constitute duress. Similarly, in the case of a great man who is forced by imprisonment and non-lethal beating to commit apostasy, one cannot imagine that he would perform taqiyya, given the tremendous nature of what is demanded of him. Matters of duress belong to that category of legal question to which one must apply the law of particular circumstances (fiqh al-hậl).
\end{abstract}

With regard to the third question, Ibn 'Atiyya states, "The scholars have agreed that taqiyya makes permissible statements of the tongue, from blasphemy on down, also sales, bequests, and divorce, freely making statements to that effect, as well as ingratiation and flattery". One justification for this position is the statement of the Companion Ibn Mas' ūd ['Abd Allāh, d. 33/653], "There is no speech I would not speak if it spared me two stripes from a man in power". Ibn "Ațiyya then explains that the lawfulness of performing deeds under the dispensation of taqiyya, as opposed to making statements, is disputed. The view that one may not perform deeds out of taqiyya was supported by the early Mālikī jurist Sahnūn [b. Sa ${ }^{1} \bar{d}$, d. 240/854], but al-Hasan [alBașrī], Makhūul [d. 112/730], and Masrūq [b. al-Ajda', d. 63/682], and

${ }^{42}$ Ibn Farḥūn, al-Dībāj al-mudhhab fì mà rifat a'yān 'ulamā' al-madhhab, pp. 275-76. 
others held that acts are permissible. Masrūq viewed it as obligatory to perform taqiyya under life-threatening circumstances; if one died when one could have dissimulated but chose not to, one would go to Hell. Sahnūn argued, to the contrary, that one would be rewarded for bravery: martyrdom was preferable to dissimulation. Al-Hasan [alBașrī] is supposed to have said that if a man is told to prostrate himself to an idol or else be killed, he should do so only if the idol is in the direction of the qibla, forming his intention to pray to God. If it is not in the direction of the qibla, then he should refuse even at risk of death. Ibn 'Atiyya rejects this opinion, remonstrating, "What prevents him from directing his intention toward God even if the idol is not in the direction of the qibla, when it is stated in the Book of God that 'No matter where you turn, there is the face of God' (Q 2:115) and when Islamic law allows the traveller to pray extra prayers in a direction other than the qibla?!" Ibn 'Atiyya ends his discussion with the statement that these are merely the main topics under the rubric of taqiyya and that its subsidiary questions are many. ${ }^{43}$

Ibn 'Ațiyya's discussion shows that dissimulation was a well-known topic in Sunni, Mālikì tafsīr and legal texts. Since al-Muharrar al-wajīz was one of the most popular commentaries with Morisco writers, there is little doubt that they would have been exposed to the concept of taqiyya ${ }^{44}$ Ibn 'Atiyya's discussion also shows that the topic of taqiyya overlaps, to a large extent, with that of duress or coercion. He discusses $i k r a \bar{h}$ in some detail in his commentary on Q 16:106, and his remarks there recapitulate his earlier discussion..$^{45} \mathrm{Ibn}$ 'Atịya presents but then dismisses the argument that only statements, and not acts, should be permitted under the dispensation of coercion.

Sales, oaths, ${ }^{46}$ divorce, manumission of slaves, breaking the fast in Ramadiann, drinking wine, and other such sins performed under coercion are matters between the worshipper and Almighty and Exalted God and are not binding on the one who performs them. This is the opinion of Mutarrif [al-Madanī, d. ca. 214/828], who

${ }^{43}$ Ibn 'Ațiyya al-Andalusī, al-Muharrar, vol. 1, p. 420.

44 Vernet, "La exégesis musulmana," p. 143 n. 26, states that this work was famosísimo in the Western half of the Arab world and used by all later authors. Ibn 'Atiyya's exegesis and al-Zamakhsharī's Kashshāf were among those most widely used by the Morisco authors of Qur'ān translations and commentaries.

${ }^{45}$ Ibn 'Ațiyya al-Andalusī, al-Muharrar, vol. 3, pp. 423-24.

${ }^{46}$ Reading aymān for ìmān in the text. 
transmitted it on the authority of Mālik, and it is the opinion of Ibn 'Abd al-Hakam [d. 214/829] and Aṣbagh [b. al-Faraj, d. 225/839], who transmitted it from Ibn alQāsim ['Abd al-Raḥmān al-'Utaqī, d. 191/806], from Mālik. Ibn 'Abbās ['Abd Allāh, d. 68/687] distinguished between what is ${ }^{47}$ a statement, like manumission and divorce, allowing dissimulation in them, and [deeds]. He said, "There is no taqiyya in what is an action, like drinking wine and breaking the fast in Ramadan. For a person under duress to do such things is not permissible". ${ }^{48}$

Again, Ibn 'Atiyya argues that one must take into account the specific circumstances and also the status of legal agent himself in judging cases of coercion.

In my view, duress should be considered according to the resolve of the one coerced, his status in the religion, and the enormity of the thing to which he is coerced. Beating might constitute duress for one thing but not another. To these cases there applies the law of particular circumstances (fiqh al-ha $\bar{a} l$ ). The oath of one coerced, as we have said, does not bind him. Ibn al-Mājishūn ['Abd al-Malik b. 'Abd al-'Aziz, d. 213-14/828-29] said, "Whether he swore to do something that is an act of obedience to God, to do something that is an act of disobedience to God, or regarding something that is neither, the oath has no effect on him". ${ }^{49}$

The early Cordoban Mālikī jurist Mutarrif (d. 220/835) reports that one may take a false oath out of taqiyya in order to protect one's person but not one's property. ${ }^{50}$

\section{Al-Qurțubì (d. 671/1272-73) on Coercion}

An extensive discussion of $i k r \bar{a} h$ occurs in the commentary on Q 16:106 in al-Qurtubī's al-Jāmi' li-ahkām al-Qur'ān. ${ }^{51} \mathrm{Abu \overline { }}$ 'Abd Allāh Muhammad b. Aḥmad b. Abī Bakr b. Faraj al-Anșārī al-Qurțubī was a native of Cordoba who became a renowned Arabic philologist and scholar of the religious sciences in the thirteenth century. He died in 671/1272-73 in Upper Egypt, presumably on the way to perform the

47 Reading $m \bar{a}$ huwa for $m \bar{a}$ hunā in the text.

48 Ibn 'Ațiyya al-Andalusī, al-Muharrar, vol. 3, p. 423.

49 Ibn 'Ațiyya al-Andalusī, al-Muharrar, vol. 3, p. 423.

50 Ibn 'Ațiyya al-Andalusī, al-Muharrar, vol. 3, p. 423.

51 Al-Qurțubī, al-Jāmi li-ahkām al-Qur'ān, vol. 10, pp. 180-91; Friedmann, Tolerance and Coercion in Islam, p. 156. A similar but shorter discussion occurs in al-Rāzì, Mafàtīh al-ghayb, vol. 20, pp. 120-23. 
pilgrimage. ${ }^{52}$ Since this is one of the best-known Mālikì tafsìr works, Ibn Abi Jum'a was presumably familiar with it. It treats the following acts, many of which also occur in Ibn Abī Jum a's fatwā: praying to an idol or prostrating to another god, praying in the wrong direction, drinking wine, eating pork, adultery or fornication, usury ( $a k l$ al-riba $)$, breaking the Ramadān fast, divorce, manumission of a slave, forced sales, marriage, and blasphemy, including insulting the Prophet. The collection of topics, the order in which they appear, and the language in which they are couched suggest that al-Qurtubỉ's discussion of ikrāh is part of the textual, legal tradition that informed Ibn Abì Jum'a's fatwa .

Al-Qurtubī's discussion uses the term ikrāh frequently throughout, and the terms mukrah, mukraha for the man or woman who is subjected to coercion. However, he uses the term taqiyya twice in reference to dissimulation without expressing disapproval of the concept. In one passage, Mālik holds that a man who fears his property will be taken by customs officers, other tyrannical officials, or attackers may not take a false oath out of taqiyya (la taqiyyata lahu fi dhälika) on the grounds that the legal dispensation is supposed to protect one's person, not one's property. ${ }^{53}$ Another passage relates the hadith report from al-Hasan alBașri: "Dissimulation (taqiyya) is permissible for the believer until the Day of Resurrection. However, God-blessed and exalted be He-allows no room for dissimulation in killing". ${ }^{54}$

Al-Qurțubi first relates the martyrdom of 'Ammār b. Yāsir's parents, Yāsir and Sumayya, and 'Ammār's outward compliance with his tormentors in Mecca. ${ }^{55}$ According to al-Qurtubī, the general principle of a dispensation for coercion is subject to consensus among Muslim jurists: "The scholars have agreed unanimously that whoever was compelled to unbelief to such an extent that he feared for his life, has not sinned if he expressed unbelief 'while his heart was at ease in belief', nor should his wife be irrevocably divorced from him, nor should he be legally recognized as an unbeliever. This is the opinion of Mālik, the Hanafiss, and al-Shāfi ${ }^{1}$, with the exception of Muhammad b. al-

52 Arnaldez, "al-Ḳurțubī”; Ibn Farhūn, al-Dībājj, pp. 406-07.

53 Al-Qurțubì, al-Jāmi' li-ahkām al-Qur'ān, vol. 10, p. 187.

${ }^{54}$ Al-Qurțubì, al-Jāmi' li-ahkām al-Qur'ān, vol. 10, p. 190.

55 Al-Qurțubī, al-Jāmi' li-ậhkām al-Qur'ān, vol. 10, pp. 179-80. 
Hasan [al-Shaybānī] (d. 189/804)". ${ }^{56}$ This dispensation for coercion with regard to blasphemy may be extended to other areas of the law.

Since Almighty and Exalted God permitted that one reject Him (al-kufr bihi) under
duress-when He is the source of the sacred law-and did not hold one to account
on that score, the scholars interpreted all of the branches of the sacred law on this
principle. If an act was coerced, then the actor should not be held accountable, and
no legal ruling ensues as a consequence. This is expressed in the well-known report
on the authority of the Prophet (may God bless him and grant him peace): "My
Community has been absolved for error, forgetfulness, and that to which they are
coerced". ${ }^{7}$

A minority of jurists, including the Mālikī jurist Sahnūn, argued that under coercion one was allowed to dissimulate in word alone, but not in deed. Al-Qurtubì insists that this view is wrong and that Mālik himself gave dispensation for coercion in both word and deed: "Ibn alQāsim [d. 191/806-07] related from Mālik that no sin can be ascribed to whoever is compelled to drink wine, to abandon prayer, or to break the fast in Ramaḍān". ${ }^{58}$ According to al-Qurtubī, one may under coercion drink wine, eat pork, eat meat that has not been slaughtered properly, break the fast in Ramaḍan, pray in a direction other than the qibla, pray to an idol or other god, or receive interest..$^{59}$ One who performs adultery or fornication under coercion is innocent. ${ }^{60} \mathrm{~A}$ coerced marriage, divorce, or manumission of a slave is invalid. ${ }^{61} \mathrm{~A}$ forced sale is invalid unless it is executed in order for a creditor to collect a debt. ${ }^{62} \mathrm{~A}$ forced admission of debt (iqrār) is invalid. ${ }^{63}$ There are, however, limits to what one may do under the dispensation of coercion. One may not, for example, kill anyone, beat or flog a Muslim, or take a Muslim's property ${ }^{64}$

What constitutes coercion is a matter of some discussion. The prevalent opinion is that circumstances under which one faces the threat of death, amputation of a limb, or severe beating, or when one is thrown into chains, imprisoned, or threatened in a frightening manner all con-

${ }^{56}$ Al-Qurțubī, al-Jāmi' li-ahkē̄m al-Qur'ān, vol. 10, p. 182.

57 Al-Qurțubī, al-Jāmi' li-aḥkām al-Qur'ān, vol. 10, pp. 181-82.

58 Al-Qurțubī, al-Jāmi' li-aḥkām al-Qur'ān, vol. 10, pp. 182-83.

59 Al-Qurțubī, al-Jāmi' li-aḥkām al-Qur'ān, vol. 10, p. 185.

${ }^{60}$ Al-Qurțubī, al-Jāmi' li-ậkām al-Qur'ān, vol. 10, pp. 183-84, p. 185.

${ }^{61}$ Al-Qurțubì, al-Jāmi' li-ahkām al-Qur'ān, vol. 10, pp. 184-185.

${ }^{62}$ Al-Qurțubī, al-Jāmi' li-ahkeàm al-Qur'ān, vol. 10, p. 184.

${ }^{63}$ Al-Qurțubī, al-Jāmi' li-aḥkām al-Qur'ān, vol. 10, p. 190.

${ }^{64}$ Al-Qurțubī, al-Jāmi' li-aḥkām al-Qur'ān, vol. 10, p. 183. 
stitute coercion. ${ }^{65}$ Others add that coercion is established not only by a threat to one's life but also by a threat to one's property ( $m \bar{a} l)$ or the honor that derives from protection of one's dependents ('ird), on the strength of the hadìth reports, inna dima'akum wa-amwālakum waa'rādakum 'alaykum harām "Your lives, property, and dependenthonor are inviolate among you" and kullu muslimin 'ala al-muslimi harāmun damuhu wa-māluhu wa- 'irduh "The life, property, and dependent-honor of every Muslim are inviolate and may not be taken by another Muslim." ${ }^{66}$ Some Hanafis limit the performer of true coercion to the ruler (sulțān), but Mālik does not. ${ }^{67}$

\section{Ibn al- Arabì (d. 543/1148) on Concealment of Faith}

The jurist Abū Bakr Ibn al- Arabī was born in Seville in 468/1076 and travelled to the East as a youth, studying with al-Ghazāli, among others, in Baghdad. He returned to Seville and served as judge there before migrating to Fez in Morocco, where he died in 543/1148. With regard to the Qur'annic passage that depicts the believing member of Pharaoh's family, he discusses the legality of concealing one's faith.

Some think that if the legally responsible Muslim conceals his faith and does not express it openly with his tongue, he is not a believer by his internal conviction alone. But Mālik said, "If a man intends in his heart to divorce his wife, it compels him, just as through his heart he becomes a believer or unbeliever", making faith depend on the heart. ... If a man forms the intention of belief in his heart, he does not become a believer until he expresses it with his tongue, but if he forms the intention of belief in his heart and caution (taqiyya) or fear prevent him from expressing it with his tongue, then that is between him and God the Exalted. Caution (taqiyya) causes him to avoid being heard by others, but it is not a condition for the legal obligation of belief to be properly fulfilled that one be heard by others. That is only required for Muslims to safeguard his life and property. ${ }^{68}$

Al-Qādị Ibn al-'Arabī stresses that it is one's internal conviction that determines one's faith, and he uses the term taqiyya explicitly in this context.

${ }^{65}$ Al-Qurțubī, al-Jāmi' li-ahkām al-Qur'ān, vol. 10, p. 190.

${ }^{66}$ Al-Qurtubīi, al-Jāmi' li-ahkēm al-Qur'ān, vol. 10, p. 187.

${ }^{67}$ Al-Qurțubì, al-Jāmi' li-aḥkām al-Qur'ān, vol. 10, p. 190.

${ }^{68}$ Ibn al-'Arabī, Ahkām al-Qur'ān, p. 1647. 


\section{Ibn al-Jallāb al-Bașrī (d. 378/988) on Coerced Apostasy}

Abū l-Qāsim 'Ubayd Allāh b. al-Ḥusayn b. al-Ḥasan, known as Ibn al-Jallāb, was an Iraqi Mālikī jurist of the tenth century. Born in Basra, he studied in Baghdad and became one of the most prominent disciples of the Mālikī authority Abū Bakr al-Abharī (d. 375/985). He authored a number of legal works, including a large commentary on the $\mathrm{Mu}$ dawwana extant in manuscript, but his most popular work was alTafri $\bar{i}$, which became a standard Mālikì legal manual. One of the few legal texts to be translated into aljamiado, it was well known among Iberian Muslims. It includes a short statement on $i k r a \bar{h}$ in the section on the punishments prescribed by Islamic penal law: "Whoever apostasizes from Islam should be asked to repent. If he repents, his repentance will be accepted, but if he refuses, then he is to be beheaded. His property becomes spoils for the Muslim community, and no heir may inherit from him, whether a Muslim or an unbeliever. Whoever is coerced (ukriha) to unbelief is not subject to penalty when 'his heart is at ease in faith" ". ${ }^{69}$ Like some other authors, Ibn al-Jallāb refers to coercion (ikrāh) and not to dissimulation (taqiyya) explicitly, but nevertheless alludes to Q 16:106 as a justification.

\section{Al-Mawwāq (d. 897/1492) on Coercion}

Abū 'Abd Allāh Muḥammad b. Yūsuf b. Abī l-Qāsim al-'Abdarī, known as al-Mawwāq, is held to be the last major Muslim jurist of the Iberian peninsula. A native of Granada, he was the leading legal authority there during the final phase of Muslim rule, and he remained there for a short time after the conquest. He wrote a number of works on law, hadith, and other topics, including a substantial commentary on a standard Mālikī legal text, the Epitome of Khalīl b. Ishạāq al-Jundī al-Mișrī (d. 767/1365), entitled al-Tāj wa-l-iklìl li-Mukhtașar Khalìl (The Crown and Tiara for the Epitome of Khalil). In the chapter devoted to drinking alcohol, he addresses coercion in general.

Regarding the permissibility that [a legally responsible Muslim] drink alcohol when he is compelled to do so, Ibn 'Arabī stated that the question has been dis-

${ }^{69}$ Ibn al-Jallāb, al-Tafrī', vol. 2, p. 231. 
puted whether a threat constitutes compulsion. The correct position is that it does constitute compulsion. If a tyrant says to [a Muslim], "If you do not do such-andsuch, I will imprison you or take your property", and [the Muslim] does not have any means to protect himself from this except God, then he may commit any act requested of him except killing someone else, for he must not save his own life by killing another. [The ruling regarding] commission of adultery [under coercion] has [also] been disputed. The correct opinion is that it is permissible to commit it and that [the coerced adulterer] should not suffer the prescribed penalty for it, contrary to the opinion of Ibn Mājishūn, for he required [the coerced adulterer] to undergo the prescribed penalty (...) Regarding [the commission] of unbelief [under coercion], that is undisputedly permissible for him, but on condition that he utter [unbelief] with his tongue while his heart is content in faith (wa-qalbuhu munsharih bi-l-īmān). Since God permitted [the Muslim] to reject Himself under coercion, the scholars have subsumed all of the branches of the sacred law under this ruling... ${ }^{70}$

This text demonstrates that the concept of $i k r a \bar{h}$ was widely recognized in the Mālikî legal tradition right up until the last generation of jurists operating under Muslim rule in the Iberian peninsula and was held to apply to nearly all areas of the sacred law.

These are some of the sources to which Moriscos and their predecessors had at least partial access and which include extensive discussions of $i k r \bar{a} h$. Others that deserve mention are the Sahīh of al-Bukhārī, the most famous work of "the six books", the standard collections of hadith accepted by Sunnis as canonical, which includes a short chapter on $i k r a \bar{h}$. Ibn Hajar al-'Asqalānī's (d. 852/1449) Fath al-bārī, a famous commentary on al-Bukhārî's work, provides a detailed account of $i k r a \bar{h}$, in many points quite similar to al-Qurțubī's discussion in alJāmi' li-ahkām al-Qur'ān. ${ }^{71}$

\section{Preemption (Istir $\left.{ }^{\circledR} \bar{a}^{\prime}\right)$ in Mālikī Legal Texts}

Mālikī jurists allow someone who divorces, marries away a daughter, gives away property, places property into an endowment, or undertakes some other legal act under duress to make a prior affidavit, attested to by legal witnesses, stating that if he undertakes the specific legal act in question at a later time he will be doing so against his will.

70 Al-Mawwāq, al-Tāj wa-l-iklīl li-Mukhtașar Khalīl, vol. 6, pp. 317-18.

${ }^{71}$ Ibn Ḥajar al-'asqalānī, Fatḥ al-bārì bi-sharh Ṣahịh al-Bukhārì, vol. 1, pp. 311-26. 
This document provides proof that the legal transaction was coerced, and when the signatory party is free from fear for his life or property, he may have the transaction voided on the strength of the prior affidavit. This type of legal preemption is termed istir ' $\bar{a}$ ', and Mālikì manuals of legal documents (shurüt or wathä'iq) discussed such affidavits beginning in the fourth/tenth century. In an answer to a petitioner's question, the Cordovan Abū Ibrāhīm Isḥāq b. Ibrāhīm al-Tujībī (d. $354 / 965$ ) explains that one may undertake istir' $\bar{a}$ ' "in every instance involving dissimulation and fear of injustice and oppression" ( $f i$ kulli mawdi' taqiyya wa-khawf min zulm wa-ghalaba). ${ }^{72}$ Ibn Farhūn's (d. 799/1397) Tabșirat al-hukkām gives examples of such affidavits. ${ }^{73}$ Many of these discussions use the explicit term taqiyya to describe the dissimulation of the coerced party; Ibn Farhūn refers to the production of this document to annul the subsequent legal action "after taqiyya has been lifted" (ba'd irtifă' al-taqiyya; ba'd zawāl al-taqiyya; idh $\bar{a}$ dhahabat al-taqiyya). ${ }^{74}$ Al-Wansharīsì (d. 914/1508) also discusses this type of affidavit in his manual al-Manhaj al-fă'iq, calling it "a contract of taqiyya" ('aqd al-taqiyya). ${ }^{75}$ In al-Mi'yār al-mu'rib, al-Wansharīsī cites al-Tujibī's discussion, also using the term taqiyya explicitly.

\section{Blasphemy, Lying, and Equivocation}

Under the general dispensation of taqiyya, the Muslim is allowed, if forced, to utter a blasphemy against Islam, whether it be a Christian creed such as the statement that Jesus is the son of God or rejection of the Prophet Muhammad. Islamic legal literature includes extensive treatments of blasphemy, termed kalimat al-kufr or alfäz al-kufr, literally "utterance of unbelief", and the subsidiary topics of invective against the Prophet (sabb al-rasül, shatm al-rasūl) and deprecation of the Companions (rafd, sabb al-ṣahāba, sabb al-shaykhayn). ${ }^{76}$ The term kalimat

${ }^{72}$ Al-Wansharīisì, al-Mi' yār al-mu' rib, vol. 6, pp. 527-28.

${ }^{73}$ Ibn Farhūn, Tabṣirat al-ḥukkām fì ușūl al-aqdiya wa-manāhij al-ahkām, vol. 2, pp. 3-6, citing the Andalusian judge Abū 1-Aṣbagh 'İsā b. Sahl (d. 486/1093) from his work al-I'Tām bi-nawāzil al-ahkā̄m.

${ }^{74}$ Ibn Farhūn, Tabṣirat al-ḥukkām, vol. 2 p. 4.

75 Al-Wansharīīi, al-Manhaj al-fă'iq wa-l-manhal al-rā'iq, p. 118.

${ }^{76}$ For example, Badr al-Dīn Muhammad b. Ismāēil al-Rashīd (d. 767/1366) wrote a work entitled Risāla fì l-alfăz al-mukaffira, and al-Qāri’ al-Harawī 'Alī b. Sulțān Muḥam- 
al-kufr, which occurs in Ibn Abī Jum 'a's fatwā, derives from Q 9:74: yahlifüna bi-llāhi annahum mā qālū wa-laqad qālū kalimata l-kufri wakafarü ba'da islämihim... "They swear by God that they did not say such a thing, yet they did utter the statement of unbelief and became disbelievers after adopting Islam ..." Ibn Abī Jum'a also advises the Moriscos that while they are permitted to lie under duress, it is preferable for them to use equivocation (tawriya) and hidden meanings (alghāz).

Ambiguous or enigmatic speech is an important category both in Arabic rhetoric and in Islamic legal thought. There are many terms for such speech, including ta' 'rìd, ma' ārìd, ma 'ārid, a 'rād, tawriya, alghāz, lahn, and malähin. Perhaps the most general term is ta 'rìd, "to say indirectly" - a synonym is talwìh- as opposed to tasrìh, "to state explicitly". This term features in a chapter of the law termed al-ta'rìd bi-l-khitba "hinting at a marriage proposal". While one may not address an explicit proposal of marriage to divorced woman or widow until her waiting period ( ' $i d d a$ ) is over, one is allowed to hint at an offer to marry her. This view is based on the Qur'ānic verse 2:235, which uses the verb 'arrada, cognate with ta' 'rìd: wa-lā junāha 'alaykum fimà 'arradtum bihi min khitbati l-nisā'i aw aknantum fi anfusikum "You commit no sin in your desires to marry women that you have hinted at or concealed in yourselves". ${ }^{77}$

Tawriya means literally to disguise or conceal, but as a rhetorical term double-entendre, equivocation, or amphibology. It is discussed in most rhetorical manuals of the late medieval period, and al-Safadi (d. 764/1363) devoted an independent work to the topic, entitled Fadd alkhitām 'an al-tawriya wa-l-istikhdām (Breaking Open the Seal, on Double-Entendre). ${ }^{78}$ Poetry that employed this rhetorical figure became extremely popular in the eighth/fourteenth century, and both Ibn Nubāta (d. 768/1366) and al-Șafadī were acknowledged experts. Tawriya refers to cases where a literal expression may be interpreted in two distinct fashions. Al-Sharîf al-Jurjānī (d. 816/1413) defines it thus: "That

$\operatorname{mad}($ d. 1014/1605-6) wrote a commentary on that work, now published as Sharh al-Imām 'Al̄̄ al-Qāri' 'alā kitāab Alfāz al-kufr li-l-'Allāma Badr al-Rashìd, ed. al-Tayyib ibn 'Umar al-Ḥusayn al-Shinqīịì, Riyad, Dār al-Faḍila, 2002.

77 Al-Shāfi ${ }^{1} \overline{1}$, Kitāb al-Umm, vol. 5, pp. 36-37.

78 Bonebakker, Some Early Definitions of the Tawriya and Safadī's Fadd al-Xitàm 'an al-tawriya wa-l-Istixdām; Bonebakker, "Tawriya"; al-Safadī, Fadd al-khitām 'an altawriya wa-l-istikhdām; Ibn Hijja al-Ḥamawī, Kitāb kashf al-lithām 'an wajh al-tawriya wa-l-istikhdām. 
the speaker intend by his speech something contrary to its obvious sense, as when one says in a battle, 'Your commander (imām) has died', intending thereby one of the men in the front lines", for imām may be interpreted as meaning "the man in front" $(a m \bar{a} m) .{ }^{79}$ Jalāl al-Dīn alSuyūṭi (d. 909/1505), who considers tawriya similar to īhām "instilling a delusion" or takhyill "causing to imagine", defines it as follows:

... that one utter an expression with two meanings, (...) one of which is near, i.e., the self-evident meaning according to custom, and the other of which is far, and that one intend the far meaning but conceal it behind the near meaning, so that the auditor imagines the apparent meaning in the first instance. For this reason, it has also been called $\bar{i}$ ăm "instilling a delusion" ${ }^{80}$

This of course fits Ibn Abī Jum a's examples in the fatwā: the audience is intended to understand the near or surface meaning, while the speaker understands the far or less obvious meaning.

Lughz, pl. alghāz, which also means concealment but as a technical term enigma, puzzle, riddle, is also well known in the Arabic rhetorical tradition. ${ }^{81}$ The phrase alghaza fi kalämihi means to conceal one's intended meaning, and the term refers most often to riddles or allegorical language, in which the speaker gives clues or hints about an intended word, statement, or topic, speaking around it without actually saying it. Allegory was of course an important part of Arabic literary tradition; Ibn Țufayl's (d. 581/1185) famous allegory Hayy ibn Yaqzān (Alive, Son of Awake) is one among many such works. ${ }^{82}$ Riddle poems based on the use of allusion were current throughout the history of post-classical Arabic literature. ${ }^{83}$ In a general sense, a lughz is any text that is expressed in allusive or allegorical language or includes a hidden mean-

79 Al-Jurjānī, Kitāb al-Ta'rīfāt, p. 71.

80 Al-Suyūțī, Sharh 'uqū al-jumān fì 'ilm al-ma'ānī wa-l-bayān, p. 112.

${ }^{81}$ Hājjī Khalīfa, Kähf al-ẓnūn 'an asāmì l-kutub wa-l-funūn, pp. 149-50; Bencheneb, "Lughz". Lughz means "enigma"; it is generally in verse and characteristically in interrogative form. Related terms are $m u$ 'amma "word puzzle" uhjiyya "riddle". Salim, Alghāz al-Harīrì wa-ahājīhi fi Maqāmātih: alghāz fiqhiyya wa-nahwiyya wa-lughawiyya wa-adabiyya; al-Ghazzī, Hāshiyat al-'ālim al-mudaqqiq al-Shaykh Ahmad Sayf al-Ghazzì al-Hanafì 'alā alghā̃z Jamāl al-Dìn 'Abd Allāh Yūsufb. Hishām al-Anșārīi; Ibn al-Shihnna, al-Dhakhà'ir al-ashrafiyya fì l-alghāz al-fiqhiyya; al-Jazā'irī, Tashìl al-majāz ilā fann almu'ammā wa-l-alghāz.

${ }^{82}$ Goodman, Ibn Tufayl's Hayy Ibn Yaqzāan: A Philosophical Tale; Heath, Allegory and Philosophy in Avicenna (Ibn Sināa).

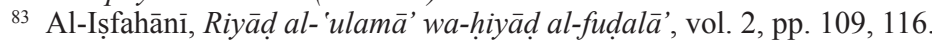


ing. The intent in this context, however, is not to challenge the interlocutor to discover the missing information, but to conceal it successfully, as a mental reservation of the speaker.

Islamic doctrine permits lying under duress. In theology, Ibn Abì Jum'a's formative influence was undoubtedly that of his teacher Muhammad b. Yūsuf al-Sanūsī (d. 895/1490), the leading scholar of Tlemcen in his day and author of three popular creeds, short, medium, and long, and a prolegomenon to the study of theology, al-Muqaddimât. ${ }^{84}$ In his Muqaddimāt, al-Sanūsī makes the following statement regarding lying:

The example of a lie that contradicts conviction ( $\left.i^{\prime} t i q \bar{a} d\right)$ is this very same statement [that animals produce voluntary actions through the power that God created in them] when a Sunni utters it in the presence of Mu'taziliss in order to conceal his condition out of fear of them. Even if it is false because it contradicts what actually obtains, it also contradicts the conviction of the Sunni who stated it, since he committed this permissible lie (kadhib mubāh) on the grounds that circumstances compelled him to it. Similar to this is the case of someone who is compelled to utter blasphemy (al-nutq bi-kalimat al-kufr) while his heart is at peace in faith (wa-qalbuhu mutma'inn bi-l-ìmān). ${ }^{85}$

This statement shows that Ibn Abì Jum 'a's most prominent teacher in the Islamic sciences addressed dissimulation and the utterance of blasphemy under coercion. A Sunni -here meaning a scholar who endorses Ash ari theology- is allowed to lie for fear of bodily harm while dissimulating in front of opponents who espouse Mu tazili doctrines.

A discussion of lying that throws additional light on Ibn Abì Jum 'a's reasoning occurs in Adab al-duny $\bar{a}$ wa-l-din, an ethical treatise by the eleventh-century Shāfíi ì scholar al-Māwardī (d. 450/1058). Islamic tradition rejects lying in strong terms, but not categorically. ${ }^{86} \mathrm{Al}$-Māwardī cites the traditional aphorism, "Lying comprises every evil and is the root of every reprehensible quality". ${ }^{87}$ The Prophet is reported to have

${ }^{84}$ Bencheneb, "al-Sanūsī;" al-Saraqusțī, al-Hiba wa-l-'atāa fì Sharh al-'Aqīda al-wusțā; al-Sanūsī, 'Umdat ahl al-tadqīq wa-l-tașdìq; 'Abd al-Lațîf Fūda, Tahdhīb Sharh al-Sanūsiyya Umm al-barāhīn; Būqalī Ḥasan, al-Imām ibn Yūsuf al-Sanūsī wa-'ilm al-tawhìd; Būqalī Hasan, al-Muqaddimāt. Les prolégomènes théologiques de Senoussi; 'Abd ai-Fattāḥ 'Abd Allāh Baraka (ed.), Sharh al-Sanūsiyya al-kubrā al-musammā, 'Umdat ahl al-tawfiq wa-l-tasdìd.

${ }^{85}$ Luciani, Les Prolégomènes de Senoussi, p. 225.

${ }^{86}$ Al-Māwardī, Adab al-dunyā wa-l-dìn, pp. 233-38.

87 Al-Māwardī, Adab al-dunyā wa-l-dīn, p. 234. 
stated that a believer could be a coward or a miser, but not a liar. ${ }^{88} \mathrm{Nev}-$ ertheless, al-Māwardī explains that one is allowed to lie under certain circumstances but should use equivocation if forced to lie.

The Sunna has transmitted permission to lie in war and in mediating disputes (ișlāh dhàt al-bayn) using equivocation (tawriya) and figurative meanings (ta'wìl), but not explicit speech (tașrì $)$, for the Sunna does not permit lying on account of the aversion it involves. Rather, this is [to be done] through equivocation (tawriya) and allusive speech (ta 'rì $d$ ). For example, when the Messenger of God (may God bless him and grant him peace) had wrapped himself in a cape, stood apart from his companions, and was asked by a man, "From whom are you?", he answered "From water $\left(\min m \bar{a}^{\prime}\right)$ ", concealing the revelation of his genealogy behind a matter that was a likely interpretation (of his speech). The questioner thought that he meant the tribe so designated [i.e., the Mā' al-Samā', tribe], but the Messenger of God intended that he came from the fluid of which man was created. So he accomplished what he desired, that is, to conceal himself, but was truthful in his speech. Similar is what is told of Abu Bakr al-Șiddīq (may God be pleased with him): that he was walking behind the Messenger of God (may God bless him and grant him peace) when he fled Mecca along with him, and was accosted by Arabs who recognized Abū Bakr but not the Messenger of God (may God bless him and grant him peace). They asked, "Abū Bakr, who is this?" and he replied, "He is a guide who is guiding me on the way." They thought that he meant showing him the way on his journey, but he meant guiding him along the path of good. Thus, he was truthful in his speech but disguised his intended meaning. ${ }^{89}$

Al-Māwardī thus deems equivocations preferable to outright lying, and the methods of doing so here involve puns, depending on two distinct meanings of the words $m \bar{a}{ }^{\prime}$-water and the name of a tribe -and $h \bar{a} d \bar{l}-$ a guide for travel in the desert and a spiritual guide.

To Ibn Sìrin (d. 110/728) is attributed the statement, al-kalāmu awsa' $u$ min an yușarraha fihi bi-l-kadhib "Speech is so extensive that one need not lie explicitly". ${ }^{90}$ One sub-chapter in al-Bukhārì's famous collection of hadith, al-Sahịh, bears the heading al-ma'ärìd mandühatun 'an al-kadhib "Equivocal speech is a way out of lying". ${ }^{91}$ Among the hadith reports included in this sub-chapter is the following, transmitted on the authority of Anas: "A son of Abū Talha died, and he asked, 'How is the boy?' Umm Sulaym replied, 'His breathing has quieted, and I hope that he is relieved now.' He believed that she was

88 Al-Māwardī, Adab al-dunyā wa-l-dìn, p. 234.

${ }^{89}$ Al-Māwardī, Adab al-dunyā wa-l-dīn, p. 237.

90 Al-Māwardī, Adab al-dunyā wa-l-dīn, p. 234.

91 Al-Māwardī, Adab al-dunyā wa-l-dīn, p. 116. 
speaking the truth". As the commentator Ibn Hajar explains, Abū Talha was led to believe that his son had recovered, but Umm Sulaym actually meant that he had died..$^{92}$ Similar statements are attributed to a number of authorities. A Prophetic hadith gives the statement inna fi $l$ ma'ärid la-mandūhatun 'an al-kadhib "Equivocal speech provides a way out of lying". ${ }^{93}$ "Umar b. al-Khattāa is supposed to have stated, inna fì l-ma 'àrìd mā yakfi an ya 'iffa al-rajulu 'an al-kadhib "Equivocal speech gives a man sufficient leeway that he may abstain from lying". ${ }^{94}$ Ibn Hajar defines ta' $r \bar{l} d$ as speech that has two senses, one of which is announced directly, while the intended meaning is the concomitant but concealed sense (kalām lahu wajhāni yutlaqu ahaduhumā wa-l-murādu lāzimuhu). ${ }^{95}$

Al-Ghazālī includes a similar discussion of lying in his ethical work Kitāb al-arba' īn fì ușūl al-dīn, which was well known in al-Andalus.

Know that lying is forbidden in every circumstance except compelling need (darüra). It even happened that a woman once said to her little son, "Come here, that I might give you something", and the Prophet (may God bless him and grant him peace) asked, "What were you intending to give him if he came?" She answered, "A date". [The Prophet] said, "If you were not to do that, a lie would be recorded against you". So let the person be wary of lying, even in his imagination and mental conversation, for that might fix in the mind a crooked image, so that the mind would give the lie to correct vision and the mysteries of the kingdom would not be revealed in sleep. Experience indicates that this is so. Certainly, lying is permitted out of dispensation when telling the truth would lead to another forbidden thing graver than lying itself, so that it becomes licit, just as carrion is permitted when not partaking in it would lead to a forbidden matter graver than eating it, which is loss of life. Umm Kulthūm (may God be pleased with her) said, "The Messenger of God only gave dispensation for lying in three cases: a man who says something in order to reconcile others, a man who says something in war, and a man speaking to his wife". This is because were the enemy to be apprised of the secrets of war, he would become bold, and were a wife to be apprised of the secrets of her husband, there might arise from her harm greater than the harm of lying. Similarly, sinning and enmity might continue indefinitely between two parties to a dispute, so if it is possible to achieve a reconciliation through lying, that is preferable. This is what has come down to us on the topic in hadith. Of equivalent status is the lie of an individual to conceal the property of someone else from a tyrant, or his denial of the secret of someone else, or his denial of his own sin against some-

92 Ibn Hajar al-'Asqalānī, Fath al-bārī bi-sharh Sậīh al-Bukhārī, vol. 10, p. 594.

93 Al-Māwardī, Adab al-dunyā wa-l-dìn, p. 234.

94 Al-Māwardī, Adab al-dunyā wa-l-dīn, p. 234.

95 Ibn Hajar, Fath al-bārī, vol. 10, p. 594. 
one else, for the open statement of sin or its revelation is forbidden, and his denial of his own crime against someone else serves to mollify him, and so does his denial to his wife that her co-wife is dearer to him. All this goes back to fending off that which is harmful. Lying is not permitted for the sake of attracting increased wealth or honor, and this is where most of people's lies occur.

Then, when one is driven to lie by compulsion (idtirāar), let him resort to equivocal speech as far as possible, so that his mind not become accustomed to lying. When Ibrāhīm b. Adham was sought at his home, he said to his maid, "Tell him to look for me in the mosque". Al-Sha "bi used to draw a circle [on the ground] and say to his maid, "Put your finger inside it, and say, 'He's not here'". A certain person used to beg out of meeting the prince, saying, "Ever since I parted with you, I have not raised my side from the ground except as Exalted God has desired". A certain person used to deny what he had said, saying, "God indeed knows I did not say anything of that" giving the impression of negation with the particle $m \bar{a}$ [ma qultu = "I did not say"] though he intended something else [ma qultu $=$ "(God knows) what I said"]. Equivocal speech is permitted for lesser (khafif) purposes, because it is justified by statements of the Prophet (may God bless him and grant him peace): "An old woman does not enter paradise"; "We will carry you on the offspring of camels"; "There is whiteness in your spouse's eyes" because these statements implied something other than what he meant. Such things are permitted with women and children to placate them through jesting. In addition, someone who refrains from eating should not lie and say, "I'm not hungry" when he is in fact hungry, but rather resort to equivocal speech. The Prophet (peace be upon him) told a woman who had said this, "Do not combine a lie and hunger". ${ }^{96}$

Al-Ghazālī's larger work, Ihyā' 'ulūm al-dīn, includes a similar discussion of lying in which he first presents statements from hadith and other sources stressing the moral perils of lying but then addresses the types of lying for which a dispensation exists..$^{97}$ This section overlaps to a great extent with the discussion of al-Māwardi presented above. Interestingly, another version of the report attributed to Umm Kulthūm is cited as adding a wife's lying to her husband to the three other categories of permissible lies-lying in order to reconcile two people involved in a quarrel, lying in war, and lying to one's wife in order to appease her. ${ }^{98} \mathrm{Al}$-Ghazāli then discusses the use of equivocal language to avoid explicit lies, cautioning about the possible abuses of this practice. ${ }^{99}$

96 Al-Ghazālī, Kitāb al-arba ìn fì ușūl al-dìn, pp. 85-86.

97 Al-Ghazālī, Ihyā' 'ulūm al-dìn, vol. 3, pp. 1020-27.

98 Al-Ghazālī, Ihyyà' 'ulūm al-dìn, vol. 3, pp. 1020-27.

99 Al-Ghazālī, Ihyyā' 'ulūm al-dìn, vol. 3, pp. 1027-29. 


\section{Al-Qurțubī's discussion of blasphemy under coercion shows im- portant similarities to that of Ibn Abī Jum 'a's fatwā, particularly in the injunction to use ambiguous language:}

Exacting scholars have said: When the coerced person utters blasphemy, then he is not permitted to let his tongue speak the words except by way of ambiguous statements (majrā al-ma'ârìd), "For in ambiguous speech there is a way out of lying" (fa-inna fì l-ma'ārìd la-mandūhatun 'an al-kadhib). When he does not do thus, he is an unbeliever, because no one has the power to control ambiguous speech (li-anna l-ma 'ârìda lā sultāna li-l-ikrāhi 'alayhi). An example is that they say to him, "Deny God" (ukfur bi-llāh) and that he say, "[I deny] the inattentive one (al-lāhì)", adding a long $-\bar{\imath}$. Similarly, if he is told, "Deny the Prophet", (ukfur $b i-l-n a b \bar{i})$, he should say that he denies the nabiyy, with geminate $-y y$, meaning "a patch of high ground", a word also used to refer to a sort of table made out of palm fronds, intending one of them in his heart while internally declaring himself innocent of unbelief and the sin of this declaration. If he is told, "Deny the Prophet" ( $u k f u r b i-l-n a b{ }_{\imath}$ ), then he should say that he denies the nabl', meaning thereby the one who brings reports, that is, any reporter whatsoever, such as [the false prophets] Tulayha and Musaylima the Liar, or he should intend thereby the nabì' of which the poet said: "[Mount al-Șāqib] would be crushed into fine pebbles * like the high sands (al-nab̄’’) around Mount al-Kāthib”. ${ }^{100}$

In another passage, al-Qurtubi returns to the topic of ambiguous speech in oaths, explaining the statement, "Ambigious speech provides a way out of lying" (innā fi ${ }^{101}$ al-ma ārìd la-mandūhatun 'an al-kadhib).

Al-A 'mash [d. 148/765] relates from Ibrāhīm al-Nakha ī [d. 96/715] that he said, "There is no harm for you to say, when something you said about a man has reached him: 'By God, God knows, I did not say ( $m \bar{a}$ qultu) anything of the sort about you' (wa-llāhi inna llāha ya 'lamu mā qultu fika min dhālika min shay')". 'Abd al-Malik b. Habīb [d. 238/852] explains: "This means that God knows what I said ( $m \bar{a}$ qultu) (...), when in its apparent meaning it negates having said it. One who says this commits neither perjury in his oath nor a lie in ordinary speech". AlNakha ${ }^{1} \overline{\text { said, }}$ "They [the early Arabs] would use enigmatic oaths (alghāz al-aymān) in their speech in order protect themselves. They did not see this as lying and did not fear breaking their oaths thereby. "Abd al-Malik said: "They would call this 'equivocal speech' (al-ma 'ầìd min al-kalām) if it was not done to thwart a right through cunning and deception". Al-A 'mash said, "When someone whom Ibrāhīm al-Nakha ${ }^{e} \overline{\text { did }}$ not want to meet came to see him, he would sit in the prayer corner of his room (masjid baytihi), and then tell his servant-girl, "Tell him, 'He, by God, is in the mosque (masjid)'", Mughìra related from Ibrāhīm that he used to permit

100 Al-Qurțuīi, al-Jāmi' li-ahkām al-Qur'ān, vol. 10, pp. 187-88. On this verse by Aws b. Hajar, see Lane, Arabic-English Lexicon, vol. 1, p. 1.029.

101 For min in the text. 
a man from the army, when they presented themselves to their commander, to swear, "By God, I will only follow the path that someone other than me (ghayri) sets for me, I will only ride that on which someone other than me mounts me", and statements of this sort. "Abd al-Malik comments, "He intends God, the Exalted, by his statement, "someone other than me" (ghayrì), for God is the one who set him on a path, and God is the one who has given him a mount. They did not see that the man had broken his oath in this manner, or that he had lied in his speech, but they disapproved of saying such things in cases of trickery, oppression, or denial of a right. He who has the audacity to do the latter has sinned in his trickery, but is not obliged to atone for his oath. ${ }^{102}$

Islamic legal tradition condones the use of ambiguous language as a means to protect oneself from the effects of a forced oath or of one's refusal to take such an oath. The main scriptural texts cited in support of this practice are the hadith reports mentioned above that present equivocal speech ( $m a^{\prime}$ ârì al-kaläm) as an alternative to lying. In general, when a man is unjustly forced to swear, his oath should be interpreted according to his own intention, but when he is forced to swear after committing some injustice, his oath should be interpreted according to the intention of the one enforcing the oath. ${ }^{103}$

The famous philologian Ibn Durayd al-Azdī (d. 321/933) penned Kitāb al-malāhin in order to serve the needs of people who faced mandatory oaths. In it he presents 183 oaths that are double-entendres or amphibologies, the obvious meaning intended for the tyrannical ruler or his agents who are administering the oath, and the other, not-so-obvious meaning understood internally by the oath-taker. The title of the work, al-malăhin, derives from lahn, meaning to intend one thing but to disguise or conceal it behind another statement (an turída al-shay'a fa-tuwarriya 'anhu bi-qawlin ākhar). ${ }^{104} \mathrm{He}$ explains, "This is a book that we have composed as a resort for an oppressed person who is constrained and compelled to take an oath. He should say openly (yu'ärid) what we have recorded and hold internally (yudmir) the opposite of

102 Al-Qurțubī, al-Jāmi` li-ahkām al-Qur'ān, vol. 10, pp. 190-91. Here, al-Qurțubī seems to be quoting extensively from a work by the prominent early Mālikî jurist and native of Cordoba, 'Abd al-Malik b. Habīb, perhaps Kitāb al-Wādiha fì l-sunna wa-l-fiqh. See Ossendorf-Conrad, Das «Kitāb al-Wädiha» des 'Abd al-Malik b. Habīb: Edition und Kommentar zu ms. Qarawiyyīn 809/40 (abwǟb al-țahāra); Arcas Campoy, Kitāb al-Wāạiha (tratado jurídico): Fragmentos extraídos del Muntajab al-ạ̣kām de Ibn Abī Zamanīn (m. 399/1008).

${ }^{103}$ Schacht, "Hiyal", esp. 512.

104 Ibn Durayd al-Azdī, Kitāb al-malāhin, p. 56. 
that which he puts forth externally, so that he might be safe from the misdeed of the oppressor and escape the wrath of the tyrant". ${ }^{105}$ For example, one might swear wa-llāhi mā sa'altu fulānan hājatan qațtu "By God, I have not asked So-and-so for anything at all". The interlocutor will understand hāja in its ordinary meaning "need, thing, anything", but the oath-taker will intend by hajja a specific type of thorn-bearing tree. ${ }^{106}$ The oath wa-llāhi mā ra'aytu fulānan qațtu walā kallamtuhu would seem to mean "By God, I have neither seen Soand-so at all, nor have I spoken to him", but the oath-taker will mean by $m \bar{a}$ ra'aytuhu "I haven't struck him in the lung (ri'a)" and by $m \bar{a}$ kallamtuhu "I haven't wounded him". ${ }^{107}$ The oath wa-llähi ma akhadhtu li-fulānin bazzan wa-mà lahu 'ind̄ min bazz would seem to mean, "By God, I have not taken any cloth from So-and-So, and I do not have any cloth that belongs to him", but the oath-taker will intend by bazz "weapons" instead. ${ }^{108}$ Ibn Durayd's work was not the only one of its kind: the medieval sources mention several similar works that are no longer extant. Abū 'Abd Allāh Muḥammad b. Aḥmad al-Baṣrī al-Mufajja (d. 320/932) wrote a work with the title Kitāb al-Munqidh min al-aymān (The Book that Rescues One from Oaths). ${ }^{109}$ The Shīite scholar Abū 1-Naḍr Muhammad b. Mas ūud al- 'Ayyāshī (fl. 4th/10th c.), a native of Samarqand, wrote Kitāb Ma'ärìd al-sharr (The Book of Equivocations [in the Face] of Evil), and Yahyā b. Abì Manșūr alMawșilī (fl. 4th/10th c.) wrote Kitāb al-Ma'ārì (The Book of Equivocations). ${ }^{110}$

Such verbal amphibologies are also discussed in works on legal stratagems (hiyal). Islamic jurists devoted much thought to methods of escaping legal difficulties, and in some cases they arrived at ingenious stratagems. For example, Islamic law requires that one offer a neighbor the first option to buy one's plot of land when one would like to sell it,

105 Ibn Durayd, Kitāb al-malāhin, p. 55.

${ }^{106}$ Ibn Durayd, Kitāb al-malāhin, p. 58.

107 Ibn Durayd, Kitāb al-malāhin, p. 59.

${ }^{108}$ Ibn Durayd, Kitāb al-malāhin, p. 66.

109 Ibn al-Nadīm, al-Fihrist, p. 133 [reading al-Munqidh min al-aymān for al-Munqidh fì l-ìmān in the text]; Yāqūt al-Hamawì, Irshād al-arìb ilà ma 'rifat al-adīb, vol. 3, p. 444;

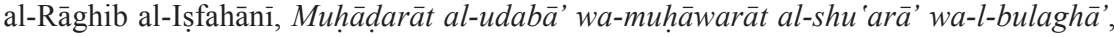
vol. 1, p. 300.

110 Ibn al-Nadīm, al-Fihrist, pp. 241, 333. 
but it often happens that one could get a better price by selling it to someone else, or one prefers for some other reason not to sell to one's neighbor. In order to avoid this, the jurists advise the owner to give away a narrow strip of his land adjacent to the neighbor's property. Since the original neighbor will no longer be a direct neighbor, the landowner may then dispose of the property as he wishes. ${ }^{111}$ Works on hiyal include explicit instructions regarding the production of verbal amphibologies, many of which involve oaths that turn on puns. If a married man wishes to travel and intends to purchase a concubine, his wife may try to forestall his return home with said concubine by making him swear that he will free any concubine he purchases before returning. He may obviate his wife's wishes without breaking the oath by swearing that he will free the concubine (jāriya) but intending instead "a boat" (jāriya). Or he may swear, "By God, I will divorce every woman that I marry and with whom I have intercourse (fa-ata'uhā)" but intend instead "whom I trample" (ata'uhāa) ${ }^{112}$ The extensive presentation of verbal amphibologies in prominent Hanafi legal works show that knowledge of such verbal ambiguity was an important facet of Islamic literature and culture, but Mālikî jurists, along with the Hanbalīs, generally condemned hiyal and considered them invalid. ${ }^{113}$

\section{Tawriya in Ibn Abì Jum'a's fatwa}

The section of Ibn Abī Jum 'a's fatwā concerning the utterance of blasphemies under duress has puzzled investigators. The aljamiado translations both omit several clauses from this section altogether, apparently because they did not understand the argument or had trouble rendering the rhetorical and grammatical terms. Harvey remarks that the text is obscure and engages in a grammatical quibble. He was least successful in paraphrasing this part of the fatwo and admits that he may

111 On hiyal in general, see Horii, "Reconsideration of Legal Devices (Hiyal) in Islamic Jurisprudence: The Ḥanafis and Their 'Exits' (Makhārij)"; Horii, Die gesetzlichen Umgehungen im islamischen Recht (hiyal) unter besonderer Berücksichtigung des Hanafiten $\mathrm{Sa}^{\prime} \mathrm{i} d \mathrm{~b}$. 'Alì al-Samarqandī (gest. 12. Jhdt.).

112 Al-Shaybānī, al-Makhārij fì l-hiyal, pp. 137-38.

113 See Ibn Qayyim al-Jawziyya, I'lām al-muwaqqi 'ìn 'an rabb al-'àlamìn, vol. 3, pp. 91-299. 
not have grasped the intended sense of the passage exactly. Rubiera Mata remarks somewhat hyperbolically that the section is impossible to translate. ${ }^{114}$ Dressendörfer's translation, the best to date, still misses certain points. For example, none of the translators has realized that the phrase bayt Allāh, literally "the house of God", refers to the Ka"ba in Mecca. Dressendörfer even complains that this example is particularly ill-chosen, because the sense of the term escaped him: "Ibn Bu Jum a hat den Trick mit dem Genitiv des Besitztums sicher irgendwo abgeschrieben, aber nicht richtig verstanden und dann das nicht richtig passende Beispiel 'das Haus Gottes' dazu erfunden". ${ }^{115}$ The following is my translation of this section of the text.

If they force you to utter blasphemy, you should resort to equivocation (tawriya) and allusions $(\operatorname{algh} \bar{a} z)^{116}$ if you are able. Otherwise, "Be at peace in your hearts in faith" 117 when you pronounce such things, and reject them [inwardly]. If they tell you to insult Muhammad, they call him Mamad-so you should insult Mamad, intending thereby the devil, or Mamad of the Jews, for this name is common among them. If they tell you to say "Jesus is the son of God", then say it, if they force you, and intend the ellipsis of a term in construct, i.e., "Jesus is the son of Mary the bondsmaid of God, Who is rightly adored". ${ }^{118}$ If they tell you to say, "Christ is the son of God", then repeat it, if you are forced, and intend thereby the genitive of possession [that is, meaning "Christ is the son who belongs to God"], as in [the expression] "the House of God" [that is, the Ka'ba at Mecca], which does not imply that God lives there, or occupies it. If they tell you to say, "Mary is His [i.e. God's] wife", then [say it] and intend the [possessive] pronoun ["his"] to refer to her paternal cousin from among the Sons of Israel, who married her then left her before consummating the marriage-according to the opinion of al-Suhaylī in his Exegesis

114 Rubiera Mata, "Los moriscos como criptomusulmanes", p. 544.

115 Dressendörfer, Islam unter der Inquisition, p. 140 n. 33.

116 Or perhaps $i \operatorname{lgh} \bar{a} z$ "using allusion", a verbal noun in parallel with tawriya.

117 A reference to Q 16:108.

118 This is an approximate rendering of the original text, which may be corrupt: 'abd ilāh Maryam ma 'büd bi-haqq "the worshipper of the god of Mary, rightly venerated". Jesus in Islamic doctrine is the son of Mary (Joseph is not identified as Jesus' father in the Qur'ān), so one would expect him to be described as her son and not the son of a worshipper. The term "son" should also appear in the statement presented. Because Ibn Abī Jum'a mentioned the ellipsis of a term in construct, one expects a statement of the form "Jesus is the son of $X$ of God", where of $X$ is the term suppressed by mental reservation. The phrase $m a$ 'büd bi-haqq occurs frequently in commentaries on the creed là ilāha illä llāh "There is no god but God", which is paraphrased as la ma 'büd bi-haqq illa llāh "There is no entity that may be correctly worshipped but God". The original must have been similar to the following in form and sense: 'Is $\bar{a}$ ibn Maryam amat allāh al-ma' büd bi-haqq "Jesus is the son of Mary, the bondswoman of God, Who is rightly adored". 
on the unspecified characters in the Qur'ān ${ }^{119}$-or intend "whom God married [i.e., to Joseph] by His decree". If they say, "Jesus died (tuwuffiya) on the Cross ( $a l \bar{a}$ $a l$-sali $b$ )", then [say it] and intend thereby that God "made him complete" (waf$f a ̆ h u$ ), that is, perfected and honored him; or, on account of his trustworthiness and steadfastness (sulb), perpetuated his memory and made praise of him known among mankind; or that God "gave him his full due" (istawfāhu) by raising him up to the heavens.

Rubiera Mata notes that Ibn Abī Jum'a's discussion draws on the multiple meanings of Arabic root combinations, and it is this aspect of the passage that has proved most difficult for translators to convey. The reference to Jesus' dying on the cross is particularly interesting in that it is based on an elaborate pun. The common interpretation of the Qur'ānic account of the crucifixion is that Jesus did not die on the cross but was saved by being taken up at the last moment by God and replaced with a substitute who looked like Jesus to the onlookers, but was not in fact he. The relevant passage in the Qur'ān reads:

They (the Jews) say in boast, 'We killed Christ Jesus the son of Mary, the Messenger of God'-They killed him not nor crucified him (salabūhu), but so it was made to appear to them, and those who differ herein are full of doubts, with no certain knowledge, but only conjecture to follow, for of a surety they killed him not. * Nay, God raised him up unto Himself (bal rafa 'ahu llāhu ilayhi); and God is Powerful, Wise. (Q 4: 157-58).

The alternative interpretations of this credal statement which Ibn Abì Jum 'a suggests are in fact puns or paronomastic double-entendres based on the consonantal roots $w-f-y$ in the verbs tuwuffiya, waffa, istawfà and s-l-b in șalìb and șulb/șalab that work only in Arabic, and not in Spanish. The jurist seems to assume that the conversation will occur in Arabic, that the puns should translate into Spanish as well, that

119 This is a reference to the work of al-Suhaylī, al-Ta 'rîf wa-l-i' làm fima ubhima min al-asmā' wa-l-a 'Tām fì l-Qur'ān al-karìm, p. 110. The passage in question reads as follows: "The name of the man to whom Mary suggested that he marry her is Joseph, son of Jacob, son of Māthān. He was her paternal cousin, and the first to notice her pregnancy. Some say that this was because he was with her in Jerusalem when her pregnancy became apparent to him, and others say that he married her and when he entered upon her, found that she was pregnant, so he turned away from her and released her, but was too chaste to mention anything but good about her, because of what he recognized in her of the intensity of her worship and her tremendous merit. The latter is the opinion of al-Qutabi (= Ibn Qutayba, d. 276/889), and the former was stated by al-Tabarī in a discussion that would take too long to present". 
all languages, when translated into inner thoughts, have a formal and semantic structure identical with that of Arabic, or that the inner thoughts of all Muslims naturally occur in Arabic.

Although Ibn Durayd does not make any specific statements about the verbal strategies on which his amphibologies are based, numerous examples in his Kitāb al-malāhin employ strategies similar to those evident in Ibn Abī Jum 'a's amphibologies. For example, he reports the oath, wa-llāhi mā dakhaltu li-fulānin baytan wa-lā ra'aytu lahu baytan, the ostensible meaning of which is "By God, I have never entered any house of So-and-So, nor have I ever seen any house of his". According to Ibn Durayd, however, by the word bayt "house" he will intend the alternative meaning "tomb" instead, or he will intend internally the completion of a genitive construct: bayt al- ankabüt "spider-web" or bayt al-nahl "bee-hive". ${ }^{120}$ Ibn Durayd also draws frequently on the various senses of Arabic verbal cognates. He interprets the oath wallāhi mā ra'aytu fulānan "By God, I have never seen So-and-So" as meaning "I have never struck him in the lung" (mā darabtu ri'atahu). ${ }^{121}$ He interprets the oath mâ a lamtu fulānan wa-là a 'lamanī "By God, I have never informed So-and-So, nor has he ever informed me" as meaning "I have never split his upper lip", that is, made him a lam ("hare-lipped"). ${ }^{122}$ In the oath wa-llāhi mā naṣaha fulānun fulānan walā yuhsinu an yanșaha "By God, So-and-So never advised So-and-So, nor is he proficient at advising", the verb "to advise" (nașaha) should be interpreted as meaning "to sew". ${ }^{123}$ In he oath wa-llāh mà akhbartu fulānan (...) "By God, I have never told So-and-So ...", the verb akhbara "to tell, inform" should be interpreted as meaning "to slaughter a khubra", that is, a sheep bought in common by a group of people to share its meat. ${ }^{124} \mathrm{Ibn}$ Abī Jum a is certainly aware of these strategies from works in the tradition, but it is difficult to identify the specific works on which he drew for this discussion.

${ }^{120}$ Ibn Durayd, Kitāb al-malāhin, p. 65.

${ }^{121}$ Ibn Durayd, Kitāb al-malāhin, p. 59.

${ }^{122}$ Ibn Durayd, Kitāb al-malāhin, p. 60.

${ }^{123}$ Ibn Durayd, Kitāb al-malāhin, p. 66.

124 Ibn Durayd, Kitāb al-malăhin, p. 67. 


\section{Conclusion}

Ibn Abī Jum'a's fatwā may be interpreted as endorsing taqiyya despite the fact that the term itself does not appear in the text. Taqiyya is an accepted principle in Sunni Islam that is discussed in fundamental sources in the fields of hadith, Qur'ānic exegesis, law, and theology with which Ibn Abī Jum a and other North African and Andalusian scholars would have been familiar. Some of these Sunni sources use the term taqiyya infrequently, treating the concept under the rubric of coercion ( $i k r a \bar{h})$, and Ibn Abī Jum'a's fatwa $\bar{a}$ does this as well, but many other sources refer to taqiyya directly and explictly. In addition, the concepts overlap, and what the mufti in this case envisaged was actually a performance of taqiyya on the part of Muslims in a hostile environment, under oppressive Christian rule. Nearly all the specific examples of the fatwa $\bar{a}$, including the discussion of equivocation in cases where Muslims are forced to blaspheme, are closely related to material found in well-known Sunni discussions of coercion. Further investigation of Islamic literature that was available in al-Andalus and North Africa will undoubtedly turn up additional references to taqiyya and ikrāh. Of the texts examined here, al-Qurțubī's discussion of coercion in al-Jāmi' li-ahkām al-Qur'ān seems most closely related to the content of Ibn Abì Jum 'a's fatwa .

What is the significance of tawriya as a means to avoid blasphemy? If one is allowed to lie in the face of danger, then why is it preferable to use tawriya instead? Competitive spirit and communal pride dictate that one defend one's religious identity. Although allowed, simple lying is nevertheless stigmatized as a cowardly act signalling a capitulation to the interlocutor and to the majority community. The value assigned to courage in the face of danger is clear from hadith reports that allow believers to deny their faith, if necessary, but reward them if they refuse to do so and choose the path of martyrdom. Tawriya allows the performer to view himself as having bested his opponents in a clever manner rather than simply giving in. He has actively appropriated the language of his oppressors and twisted its meaning so as to thwart their intentions. In a number of cases in Ibn Abī Jum 'a's fatwā, the meaning intended through tawriya not only confounds the oppressor's intention but also asserts a contrary intention, countering the oppressor's expressed ideology. This grants the performer the satisfaction of using his opponent's words against him, similar to the satisfaction derived from the common retort, but here in a possibly quite grave situation. If 
taqiyya is the shield of the believer, then tawriya is his weapon, albeit the surreptitious weapon of the weak. It is also the weapon of the clever, which serves to avoid coerced assimilation while at the same time mocking the enemy.

Sources examined to date present one concrete case in which a dissimulator consciously had recourse to the Islamic learned tradition in order to justify and guide his performance. The Morisco Ahmad b. Qāsim al-Hajarī (d. after 1050/1640) describes a difficult situation that faced him when he was asked by the ecclesiastical authorities of Granada to help decipher and interpret the Lead Books. He was not only literate but also accomplished in Arabic language and grammar, and even though the Christian authorities were seeking his assistance, he was wary about revealing how he had learned to read and write Arabic, for learning the language had been outlawed. He writes, "I asked myself, 'How do I get out of this quandary, when the Christians kill and burn everyone with whom they find a book in Arabic, or who they know reads in Arabic?"'125 He was not an old man who could claim to have learned Arabic before the prohibition, nor was he one of the few licensed translators. He therefore told 'the great priest' who interviewed him that he had learned Arabic in Madrid from a Valencian doctor who had-conveniently-died two or three years earlier and that it had been easy for him to learn because he grew up speaking Arabic dialect in his hometown. He then comments, in his account of this episode,

Everything that I told him regarding what he asked me about the doctor, i.e., that he was from Valencia, was a lie, because ${ }^{126}$ reading in Arabic was permitted to the inhabitants of Valencia on topics other than the religion of Islam, and forbidden to the remaining inhabitants of the Andalus. I thus sought protection from their evil by lying, for al-Ghazāli -may God cause others to benefit from him!- stated in the book The Revivification: 'If a good person passes by you, and then an oppressor comes chasing him, asking about him in order to harm him, then tell him, "He went in that direction!"-opposite the path he actually took, so that the man being pursued might escape the tyranny of his pursuer. Lying in such situations is permissible, or rather even recommended, despite the fact that giving correct directions is a religious obligation. It appeared to me that when someone who is customarily truthful tells a lie that is permitted to him out of compulsion, his statement is accepted, and what he says is taken to be the truth. ${ }^{127}$

${ }^{125}$ Al-Hajarī, Nāṣir al-dìn 'alā al-qawm al-kāfirìn, pp. 18-19.

126 Reading fa-li-anna for wa-lākin in the text.

127 Al-Ḥajarī, Nāṣir al-dīn, pp. 19-20. 
Al-Hajarī here provides a rare insight into the mental activity behind a concrete act of dissimulation. He was not queried directly about his beliefs, but many of the edicts of Church and State throughout the sixteenth century closely associated other cultural practices, including the ability to read Arabic, with religion and took them as evidence of heresy. Al-Hajarī justified his lies by referring to al-Ghazālì's famous work The Revivification of the Religious Sciences (Ihyà' 'ulüm al-dīn). We have mentioned al-Ghazālī's discussion of lying in this work above; the passage to which al-Hajari refers reads as follows, citing a statement by the early Iraqi scholar and Qur'ānic commentator Maymūn b. Mihrān (d. 117/735-36):

Maymūn b. Mihrān stated: Under some circumstances, lying is better than telling the truth. What do you think you would say if a man with a sword were chasing another man in order to kill him, and [the man being pursued] entered a house, then the [pursuer] accosted you, asking, 'Have you seen So-and-So?' Would you not answer, 'I have not seen him' and omit telling him the truth? Such a lie would be obligatory. ${ }^{128}$

In this case, at least, it is clear that the Morisco al-Hajarī not only practiced a form of dissimulation but also did so in the full knowledge that it was permitted by principles set forth in Islamic learned tradition. He does not use the term taqiyya, but he does refer to being compelled (mudțarr). Al-Ghazālī's Ihyā' 'ulüm al-dīn was one among a number of Islamic texts devoted to law, hadìth, and exegesis of the Qur'ān to which al-Hajarī and others like him could have had recourse in order to justify and guide their performances of dissimulation.

Investigation of the legal literature, however, will not suffice to illuminate the social history of Islamic dissimulation. Taqiyya is not merely an abstract principle to be exercised only by those who have extensive familiarity with the law. It is an important part of daily life, a method that must be performed not only in a legally correct manner, to avoid sinful acts, but also in an effective and convincing manner, to avoid bodily harm and promote the economic success and social welfare of the sectarian community. While it is important to understand the theory behind the principle, it is clear that the theoretical texts leave a great deal unsaid. Consideration of the social problems minorities generally face suggests that a different approach may provide a more

128 Al-Ghazālī, Kitāb al-arba 'ìn fì uṣūl al-dīn, vol. 3, p. 1.024.

Al-Qanțara XXXIV 2, 2013, pp. 439-490 ISSN 0211-3589 doi: 10.3989/alqantara.2013.016 
extensive understanding of taqiyya as a dynamic principle. ${ }^{129}$ Drawing on Erving Goffman's analyses of social interaction using the concepts and terminology of the theater, one may define taqiyya as a dramaturgical discipline enabling members of a stigmatized minority to participate more fully in a society dominated by a potentially hostile majority and to promote the welfare of the minority community. Even a thorough examination of extant theoretical texts focused on the issue may leave many important questions unanswered. ${ }^{130}$ For a Morisco to pass as a good Christian took more than a simple statement to that effect. It required a sustained performance involving hundreds of individual statements and actions of different types, many of which might have had little to do with expressions of belief or ritual practice per se.

Dissimulation was an institutionalized practice in Morisco communities that involved regular patterns of behaviour passed on from one generation to the next. Many of the performers were not literate in Arabic and so would not have had access to discussions of taqiyya as a legal principle. Moreover, many of the particular dissimulatory practices they adopted were not discussed in such literature at all. For example, the Moriscos performed a ceremony immediately after Christian baptism termed fada or fadas, by which they erased or removed the effects of baptism by washing the baby and performing ritual ablutions, after which they would give the child a Muslim name. ${ }^{131}$ In his analysis of the use of taqiyya by Shì ites in Afghanistan, Louis Dupree suggests that it is important to recognize taqiyya as both a theory and a practice: "... it may be prudent to define the meaning of taqiyya in two distinct ways: the way local religious leaders interpret it, and the way it functions in the day-to-day lives of the peoples involved. Neither definition, however, precludes the validity of the other". ${ }^{132}$ There is reason to believe that Morisco dissimulation resembled that of other historical groups, including Shì'ites living under oppressive Sunni rule, and showed similar patterns regarding the relationship between theory and

129 See, for example, Goffman, Stigma: Notes on the Management of Spoiled Identity; Jones et al., Social Stigma: The Psychology of Marked Relationships; Richards, Sex, Dissidence and Damnation: Minority Groups in the Middle Ages; Schaefer, Racial and Ethnic Groups.

${ }^{130}$ See Stewart, "Taqiyyah as Performance;" Stewart, "Documents and Dissimulation."

131 García-Arenal, Inquisición y moriscos, pp. 56-59; Boronat y Barrachina, Los Moriscos españoles y su expulsión, p. 225.

132 Dupree, "Further Notes on Taqiyya", p. 681. 
practice. Morisco peasants would not have been able to cite treatments of taqiyya in legal manuals, even though they were actively dissimulating in various ways in the course of their daily lives. In Shì ite contexts scholars complain that lay Shīeites are not sufficiently schooled in the ramifications and extent of taqiyya as a legal dispensation and do not know how to use it properly, confirming a communication gap between the two groups. ${ }^{133}$ Nevertheless, even illiterate Shīites in Afghanistan, Pakistan, and Saudi Arabia are not cut off from the learned doctrinal tradition entirely and are aware of the general concept of taqiyya and the permissibility of using it in their daily lives. It is reasonable to assume that a similar situation held for less educated Moriscos. However, in a city like Granada, home to highly literate and educated Muslims with a local tradition of Islamic legal scholarship, a considerable number of inhabitants must have been aware of the finer points of Islamic law regarding dissimulation and duress.

\section{Bibliography}

'Abd al-Fattāḥ 'Abd Allāh Baraka (ed.), Sharh al-Sanūsiyya al-kubrāa almusammā, 'Umdat ahl al-tawfí wa-l-tasdīd, Kuwait, Dār al-Qalam, 1982.

'Abd al-Lațîf Fūda, Sa īd, Tahdhīb Sharh al-Sanūsiyya Umm al-barāhīn, Amman, Dār al-Bayāriq, 1998.

Abdur Rahim, The Principles of Muhammadan Jurisprudence: according to the Hanafi, Maliki, Shafi 'i and Hanbali Schools, London, Luzac, 1911.

Abou El Fadl, Khaled, "Islamic Law and Muslim Minorities: The Juristic Discourse on Muslim Minorities from the Second/Eighth to the Eleventh/Seventeenth Centuries", Islamic Law and Society, 1 (1994), pp. 141-87.

Abou El-Fadl, Khaled, "The Common and Islamic Law of Duress", Arab Law Quarterly, 6 (1991), pp. 121-59.

Abū Șafiya, Fakhrī, al-Ikrāh fì l-sharì a al-islāmiyya, Algiers, Sharikat al-Shihāb, 1982.

Adang, Camilla P., "Hypocrites and Hypocrisy", Encyclopaedia of the Qur'ān, Leiden, Brill, 2002, vol. 2, pp. 468-72.

Arcas Campoy, María, Kitāb al-Wādiha (tratado jurídico: Fragmentos extraídos del Muntajab al-ahkeām de Ibn Abī Zamanīn (m. 399/1008), Madrid, CSIC, 2003.

${ }^{133}$ Stewart, "Taqiyyah as Performance”, pp. 28-29.

Al-Qanțara XXXIV 2, 2013, pp. 439-490 ISSN 0211-3589 doi: 10.3989/alqantara.2013.016 
Arnaldez, R., “al-Kurtubì”, in P.J. Bearman et al. (eds.), Encyclopcedia of Islam, 2nd edition, Leiden, Brill, 1960-2005.

Barletta, Vincent, Covert Gestures: Crypto-Islamic Literature as Cultural Practice in Early Modern Spain, Minneapolis, Minnesota Press, 2005.

Al-Bayḍ̄āī, Anwār al-tanzīl, Hyderabad, al-Maṭba a al- 'Uthmāniyya, 1911.

Bencheneb, M., "al-Sanūsī”, in P.J. Bearman et al., Encyclopcedia of Islam, 2nd edition, Leiden, Brill, 1960-2005.

Bencheneb, M., "Lughz", in P.J. Bearman et al., Encyclopcedia of Islam, 2nd edition, Leiden, Brill, 1960-2005.

Bonebakker, Seeger Adrianus, Some Early Definitions of the Tawriya and Safadì's Fadd al-Xitām 'an al-Tawriya wa-l-Istixdām, The Hague, Mouton \& Co., 1967.

Bonebakker, Seeger Adrianus, “Tawriya”, in P.J. Bearman et al., Encyclopcedia of Islam, 2nd edition, Leiden, Brill, 1960-2005.

Boronat y Barrachina, Pascual, Los moriscos españoles y su expulsión, Granada, Universidad, 1992.

Bouzineb, Hossain, "Respuestas de jurisconsultos magrebíes en torno de la inmigración de musulmanes hispánicos”, Hespéris-Tamuda, 26-27 (1988-89), pp. 53-66.

Būqalī, Ḥasan Jamāl al-Dīn, al-Imām ibn Yūsuf al-Sanūsì wa- 'ilm al-tawhìd, Algiers, al-Mu'assasa al-Wațaniyya li-l-Kitāb, 1985.

Būqalī Ḥasan, Jamāl al-Dīn, al-Muqaddimāt. Les prolégomènes théologiques de Senoussi; texte arabe et traduction française par J. D. Luciani, Algiers, Imprimerie P. Fontana, 1908.

Burhān al-Dīn Abū l-Ḥasan 'Alī b. Abī Bakr al-Farghānī al-Marghīnānī, al-Hidāya sharh Bidāyat al-mubtad̄̄, Muḥammad 'Adnān Darwīsh (ed.), Beirut, Dār alArqam b. Abī l-Arqam, n.d., 2 vols., English translation, in Charles Hamilton (transl.), The Hedaya, or Guide: A Commentary on the Mussulman Laws, London, W.H. Allen, 1870, 2nd ed.

Cardaillac, Louis, Morisques et Chrétiens: un affrontement polémique (14921640), Paris, Librairie Klincksieck, 1977.

Cardaillac, Louis, "Un aspecto de las relaciones entre moriscos y cristianos: polémica y taqiyya", in A. Galmés (coord.), Actas del coloquio internacional sobre literatura aljamiada y morisca, Madrid, Gredos, 1978, pp. 107-22.

Chejne, Anwar G., Islam and the West: The Moriscos, A Cultural and Social History, Albany, State University New York Press, 1983.

Cheneb, M., "al-Sanūsī”, in M.Th. Houtsma, T.W. Arnold, R. Basset, A.J. Wensinck, E. Lévi-Provençal y H.A.R. Gibb (eds.), The Encyclopcedia of Islam, Leiden, Brill, 1913-38.

Clarke, Lynda, "The Rise and Decline of Taqiyya in Twelver Shi ism", in Todd Lawson (ed.), Reason and Inspiration in Islam: Theology, Philosophy and Mysticism in Muslim Thought, London, I.B. Tauris, 2005, pp. 46-63. 
Cornell, Vincent J., "'Ilm al-Qur'ān in al-Andalus: The Tafsìr Muharrar in the Works of Three Authors", JUSÜR, 2 (1986), pp. 63-81.

Dakake, Maria, "Hiding in Plain Sight: The Practical and Doctrinal Significance of Secrecy in Shi ite Islam", Journal of the American Academy of Religion, 74 (2006), pp. 324-55.

Donaldson, Dwight M., The Shi'ite Religion: A History of Islam in Persia and Irak, London, Luzac, 1933.

Dressendörfer, Peter, Islam unter der Inquisition: Die Morisco-Prozesse in Toledo 1575-1610, Wiesbaden, Franz Steiner, 1971.

Dupree, Louis, "Further Notes on Taqiyya: Afghanistan", Journal of the American Oriental Society, 99, 4 (1979), pp. 680-82.

Epalza, Míkel de, "La voz oficial de los musulmanes hispanos, mudéjares y moriscos, a sus autoridades cristianas: cuatro textos, en árabe, en castellano y en catalán-valenciano", Sharq al-Andalus, 12 (1995), pp. 279-98.

Epalza, Míkel de, "L'identité onomastique et linguistique des Morisques", in Religion, Identité et Sources Documentaires sur les Morisques Andalous, Tunis, Institut Supérieur de Documentation, 1984, pp. 269-79.

Fawzī, Muḥammad, Mafhūm al-taqiyya fì l-Islām, Beirut, Mu'assasat al-Wafā', 1985.

Fierro, Maribel, "La emigración en el Islam: conceptos antiguos, nuevos problemas", Awrāq, 12 (1991), pp. 11-41.

Friedmann, Yohanan, Tolerance and Coercion in Islam: Interfaith Relations in the Muslim Tradition, Cambridge, Cambridge University Press, 2003.

Galmés de Fuentes, Álvaro, Los moriscos (desde su misma orilla), Madrid, Instituto Egipcio de Estudios Islámicos, 1993.

García-Arenal, Mercedes, Inquisición y Moriscos: los procesos del Tribunal de Cuenca, Madrid, Siglo Veintiuno, 1978.

Al-Ghazālī, Abū Ḥāmid, Ihyyà' 'ulūm al-dīn, Cairo, Dār al-Wathā'iq, 2000.

Al-Ghazālī, Abū Ḥāmid, Kitāb al-arba ìn fì uṣūl al-dīn, Beirut, Dār al-Āfāq alJadīda, 1982.

Al-Ghazzī, Ahmad Sayf, Hāshiyat al-'ālim al-mudaqqiq al-Shaykh Ahmad Sayf al-Ghazzì al-Hanafì 'alā Alghāz Jamāl al-Dīn 'Abd Allāh Yūsuf b. Hishām al-Anșārī, published with Khālid al-Azharī, al-Alghāz al-madhkūra, Cairo, al-Maṭa a al-I'lāmiyya, 1886-87.

Goffman, Erving, Stigma: Notes on the Management of Spoiled Identity, New York, Simon and Schuster, 1986.

Goldziher, Ignaz, "Das Prinzip der takijja im Islam", Zeitschrift der deutschen morgenländischen Gesellschaft, 59 (1906), pp. 213-26.

Goodman, Lenn E., Ibn Tufayl's Hayy Ibn Yaqzānn: A Philosophical Tale, Chicago, University of Chicago Press, 2009.

Gordon, Cyrus, "The Substratum of Taqiyya in Iran", Journal of the American Oriental Society, 97 (1977), p. 192. 
Guadalajara y Xavier, Fray Marcos de, Memorable expulsión y justísimo destierro de los Moriscos de España, Pamplona, Nicolás de Assiayn, 1613.

Al-Hajarī, Aḥmad b. Qāsim, Nāṣir al-dīn 'alā al-qawm al-kāfirīn, P.S. Van Koningsveld, Qāsim al-Sāmarrā'ì and Gerard Wiegers (eds.), Madrid, CSIC, 1997.

Hājjī Khalīfa, Katip Çelebi, Kashf al-ẓunūn 'an asāmì l-kutub wa-l-funūn, Istanbul, Maarif Matbaas1, 1941-55, 6 vols.

Harvey, Leonard Patrick, "Crypto-Islam in Sixteenth-Century Spain", in Actas del Primer Congreso de Estudios Árabes e Islámicos (Córdoba, 1962), Madrid, Comité Permanente del Congreso de Estudios Árabes e Islámicos, 1964, pp. 163-179.

Harvey, Leonard Patrick, Muslims in Spain, 1500-1614, Chicago, Chicago University Press, 2005.

Harvey, Leonard Patrick, The Literary Culture of the Moriscos (1492-1609): A Study Based on the Extant Manuscripts in Arabic and Aljamia, Oxford, D. Phil. diss., 1958, 2 vols.

Harvey, Leonard Patrick, "The Political, Social and Cultural History of the Moriscos", in Salma Khadra Jayyusi (ed.), The Legacy of Muslim Spain, Leiden, Brill, 1994, pp. 201-234, 2 vols.

Harvey, Leonard Patrick, "Una referencia explícita a la legalidad de la práctica de la taqiya por los moriscos", Sharq al-Andalus, 12 (1995), pp. 561-63.

Heath, Peter, Allegory and Philosophy in Avicenna (Ibn Sinā), Philadelphia, University of Pennsylvania Press, 1992.

Horii, Satoe, Die gesetzlichen Umgehungen im islamischen Recht (hiyal) unter besonderer Berücksichtigung des Hanafiten Sa 'ìd b. 'Alì al-samarqandī (gest. 12. Jhdt.), Berlin, Klaus Schwarz Verlag, 2001.

Horii, Satoe, "Reconsideration of Legal Devices (Hiyal) in Islamic Jurisprudence: The Hanafīs and Their 'Exits' (Makhārij)", Islamic Law and Society, 9, 3 (2002), pp. 312-57.

Al-Ḥusaynī, 'Abd al-Fattāḥ, al-Ikrāh wa-atharuh fì l-ahkām al-shar'iyya: dirāsa muqārana qā'ima 'alā al-istiqșā' li-l-furū' al- 'aqā'idiyya wa-l-fiqhiyya, Cairo, Dār al-Ittiḥād al-'Arabī, 1979.

Ibn Abī Zamanīn, Tafsìr, Beirut, Dār al-Kutub al-'Ilmiyya, 2003, 2 vols.

Ibn al-'Arabī, al-Qāḍī, Ahkām al-Qur'ān, 'Alī Muḥammad al-Bijāwī (ed.), Cairo, 'Îsā al-Bābī al-Halabīi, 1968, 1 vol. in 4.

Ibn 'Atiyya al-Andalusī, Abū Muhammad 'Abd al-Ḥaqq b. Ghālib, al-Muharrar al-wajīz fi tafsìr al-Kitāb al- 'azìz, 'Abd al-Salām 'Abd al-Shāfì Muhammad (ed.), Beirut, Dār al-Kutub al-'Ilmiyya, 1993, 6 vols.

Ibn Durayd al-Azdī, Abū Bakr Muḥammad b. al-Ḥasan, Kitāb al-malāhin, 'Abd al-Ilāh Nabhān (ed.), Beirut, Maktabat Lubnān Nāshirūn, 1996.

Ibn Farhūn, al-Dībāj al-mudhhab fì ma' 'rifat a 'yān 'ulamā' al-madhhab, Ma'mūn b. Muḥyī al-Dīn al-Jannān (ed.), Beirut, Dār al-Kutub al-'Ilmiyya, 1996. 
Ibn Farhūn, Tabșirat al-hukkām fì uṣūl al-aqdiya wa-manāhij al-ahkām, Riyad, Dār 'Ālam al-Kutub, 2003, 2 vols.

Ibn Hajar al-'Asqalānī, Fath al-bārī bi-sharh Ṣaḥ̄h al-Bukhārī, Cairo, Muṣtafāà al-Bābī al-Halabī, 1959-78, 13 vols.

Ibn Hijja al-Hamawī, Taqī al-Dīn Abū Bakr b. 'Alī, Kitāb kashf al-lithām 'an wajh al-tawriya wa-l-istikhdām, Beirut, al-Mațba a al-Unsiyya, 1894.

Ibn al-Jallāb, al-Tafrī', Husayn b. Sālim al-Dahmānī (ed.), Beirut, Dār al-Gharb al-Islāmī, 1987, 2 vols.

Ibn Kathīr, Tafsìr al-Qur'ān al- 'aẓim, Beirut, Dār al-Mårifa, 1986, 4 vols.

Ibn al-Nadīm, al-Fihrist, 'Alī al-Ṭawīl (ed.), Beirut, Dār al-Kutub al-'Ilmiyya, 1996.

Ibn Qayyim al-Jawziyya, I'lām al-muwaqqi'ìn 'an rabb al-'ālamìn, Muhammad 'Abd al-Salām Ibrāhīm (ed.), Beirut, Dār al-Kutub al- 'Ilmiyya, 1991, 4 vols.

Ibn al-Shiḥna, 'Abd al-Barr b. Muḥammad, al-Dhakhā'ir al-ashrafiyya fì l-alghāz al-fiqhiyya, Muḥammad 'Adnān Darwīsh (ed.), M.A. Darwish, Damascus, Dar al-Majd, 1994.

Ibn Taymiyya, Minhāj al-sunna, Beirut, Dār Șādir, 1973, 4 vols.

Ibrahim, Areeg, "Literature of the Converts in Early Modern Spain: Nationalism and Religious Dissimulation of Minorities", Comparative Literature Studies, 45, 2 (2008), pp. 210-27.

Al-Jașșāṣ, Abū Bakr, Aḥkām al-Qur'ān, Beirut, Dār Iḥyā' al-Turāth al-'Arabī, 1992, 5 vols.

Al-Jazā’irī, Ṭāhir b. Șāliḥ, Tashīl al-majāz ilā fann al-mu ammā wa-l-alghāz, Damascus, Maṭba'at Wilāyat Sūriya, 1886.

Jones, Edward E. et al., Social Stigma: The Psychology of Marked Relationships, New York, W.H. Freeman and Co., 1984.

Al-Jurjānī, Alī b. Muhammad al-Sharīf, Kitāb al-Ta'rīfāt, Beirut, Dār al-Kutub al-'Ilmiyya, 1995.

Al-Kalbī, Muḥammad al-Qāsim b. Aḥmad b. Juzayy, Kitāb al-tashīl li-'ulūm altanzīl, Beirut, Dār al-Kitāb al-'Arabī, 1973, 4 vols.

Kohlberg, Etan, "Some Imāmī-Shī'ī Views on Taqiyya", Journal of the American Oriental Society, 95 (1975), pp. 395-402.

Kohlberg, Etan, "Taqiyya in Shīè Theology and Religion”, in Hans G. Kippenberg and Guy G. Stroumsa (eds.), Secrecy and Concealment: Studies in the History of Mediterranean and Near Eastern Religions, Leiden, Brill, 1995, pp. 345-80.

Lane, Edward William, Arabic-English Lexicon, Cambridge, Islamic Texts Society, 1984, 2 vols.

Layish, Aharon, "Taqiyya among the Druzes", Asian and African Studies, 19 (1985), pp. 245-81.

López-Morillas, Consuelo, The Qur'ān in Sixteenth-Century Spain: Six Morisco Versions of Sūra 79, London, Tamesis Books, 1982.

Luciani, J.D., Les Prolégomènes de Senoussi, Algiers, Imprimerie Orientale Pierre Fontana, 1908. 
Maclean, Ian, Meaning and Interpretation in the Renaissance: The Case of Law, Cambridge, Cambridge University Press, 1991.

Makārim, Sāmī, al-Taqiyya fi l-Islām, London, Druze Heritage Foundation, 2004. Al-Māwardī, Adab al-dunyā wa-l-dīn, Beirut, Dār al-Kutub al-'Ilmiyya, 1987.

Al-Mawwāq, al-Tāj wa-l-iklīl li-Mukhtașar Khalīl, printed on the margin of Abū 'Abd Allāh Muḥammad b. Muḥammad b. 'Abd al-Raḥmān al-Ḥațāo al-Maghribī (d. 954/1547), Mawāhib al-jalīl li-sharh Mukhtaṣar Khalīl, Cairo, Mațba at al-Sa āda, 1911, 6 vols.

Meyer, Egbert, "Anlass und Anwendungs bereichder taqiyya”, Der Islam, 57 (1980), pp. 246-80.

Miller, Kathryn A., Guardians of Islam: Religious Authority and Muslim Communities of Late Medieval Spain, New York, Columbia University Press, 2008.

Mīrzā 'Abd Allāh al-Iṣfahānī, Riyāẹ al-'ulamā' wa-hiyā ḍ al-fuḍalā', Sayyid Ahmad al-Husaynī (ed.), Qum, Maṭba at al-Khayyām, 1980, 6 vols.

Molénat, Jean-Pierre, "Le problème de la permanence des musulmans dans les territoires conquis par les chrétiens, du point de vue de la loi islamique", Arabica, 48 (2001), pp. 394-400.

Montaigne, Michel de, “Du dementir”, Essais, M. Rat (ed.), Paris, Garnier, 1962, 2 vols.

Ossendorf-Conrad, Beatrix, Das «Kitāb al-Wädiha» des 'Abd al-Malik b. Habīb: Edition und Kommentar zu ms. Qarawiyyìn 809/40 (abwāb al-țahāra), Stuttgart, F. Steiner, 1994.

Perry, Mary Elizabeth, The Handless Maiden: Moriscos and the Politics of Religion in Early Modern Spain, Princeton, Princeton University Press, 2005.

Pormann, Peter E., "Das Fatwa Die Herrlichsten Waren (Asnā l-matāğir des alWanšarīsī)", Der Islam, 80 (2003), pp. 301-28.

Al-Qāḍi 'Abd al-Jabbār, Tathbìt dalà'il al-nubuwwa, 'Abd al-Karīm 'Uthmān (ed.), Beirut, Dār al-`Arabiyya, 1966.

Al-Qāri' al-Harawī 'Alī b. Sultān Muhammad, Sharh al-Imām 'Alī al-Qāri' 'alā kitāb Alfàz al-kufr li-l-'Allāma Badr al-Rashīd, al-Tayyib ibn 'Umar al-Husayn al-Shinqî̀īi (ed.), Riyad, Dār al-Faḍīla, 2002.

Al-Qurțubī, Muhammad b. Aḥmad, al-Jāmi' li-ahkām al-Qur'ān, Aḥmad 'Abd al-'Alīm al-Bardūnī et al. (eds.), Beirut, Dār Ihyā' al-Turāth al-'Arabī, 1985, 20 vols.

Al-Rāghib al-Iṣfahānī, Muḥ̄ạarāt al-udabā' wa-muhāawarāt al-shu 'arā' wa-l-bulagh $\bar{a}$, Cairo, al-Matba a al-'Āmira al-Sharafiyya, 1908.

Al-Rāzī, Fakhr al-Dīn, Mafātīh al-ghayb [al-Tafsìr al-kabìr], Cairo, al-Maṭba'a al-Bahiyya al-Mișriyya, 1938, 32 vols.

Razūq, Muhammad, al-Andalusiyyūn wa-hijrātuhum ilā al-Maghrib khilāl alqarnayn 16-17, Casablanca, Ifrīqiya al-Sharq, 1989.

Richards, Jeffrey, Sex, Dissidence and Damnation: Minority Groups in the Middle Ages, London, Routledge, 1990. 
Rubiera Mata, María Jesús, "Los moriscos como criptomusulmanes y la Taqiyya", in Actas del Simposio Internacional de Mudejarismo (IX), Teruel, Instituto de Estudios Turolenses, 2004, pp. 537-47.

Sabbagh, Leila, "La religion des Moriscos entre deux fatwas", in Les Morisques et leur temps. Table Ronde Internationale 4-7 Juillet 1981, Montpellier, Paris, Éditions du Centre Nationale de la Recherche Scientifique, 1983, pp. 45-56.

Al-Ṣafadī, Khalīl b. Aybak, Faḍ al-khitām 'an al-tawriya wa-l-istikhdām, alMuhammadī 'Abd al-`Azīz al-Hinnāwī (ed.), Cairo, Dār al-Ṭibāéa al-Muhammadiyya, 1979.

Salīm, Muhammad Ibrāhīm (ed.), Alghāz al-Harīrī wa-ahājīhi fì Maqāmātih: alghāz fiqhiyya wa-nahwiyya wa-lughawiyya wa-adabiyya, Cairo, Maktabat Ibn Sīnā, 1988.

Al-Sanūsī, Muḥammad b. Yūsuf, 'Umdat ahl al-tadqīq wa-l-taṣdīq, Cairo, Dār Ihyā' al-Kutub al-'Arabiyya, n.d.

Al-Saraqusțī, Abū Isḥāq al-Andalusī, al-Hiba wa-l- ațā fì Sharḥ al-'Aqīda alwusțā, Tunis, al-Maktaba al-'Ilmiyya, 1926-27.

Schacht, J., "Hiyal", in P.J. Bearman et al. (eds.), Encyclopcedia of Islam, 2nd edition, Leiden, Brill, 1960-2005.

Schaefer, Richard T., Racial and Ethnic Groups, New York, Harper Collins, 1993.

Al-Shāfi īi, Kitāb al-Umm, Beirut, Dār al-Fikr, 1973, 8 vols.

Al-Shaybānī, Muḥammad b. al-Ḥasan, al-Makhārij fi l-ḥiyal, Cairo, Dār al-Thaqāfa al-Dīniyya, 1999.

Stewart, Devin J., "Documents and Dissimulation: Notes on the Performance of Taqiyya", in Cristina de la Puente (ed.), Identidades marginales, Madrid, CSIC, 2003, Estudios onomástico-biográficos de al-Andalus (EOBA) XIII, pp. 569-98.

Stewart, Devin J., "Husayn b. 'Abd al-Șamad al- 'Āmilī’s Treatise for Sultan Suleiman and the Shī ${ }^{-1}$-Shāfi ${ }^{1} \overline{1}$ Legal Tradition", Islamic Law and Society, 4 (1997), pp. 156-99.

Stewart, Devin J., Islamic Legal Orthodoxy: Twelver Shiite Reactions to the Sunni Legal System, Salt Lake City, Utah University Press, 1998.

Stewart, Devin J., "Taqiyyah as Performance: The Travels of Bahā' al-Dīn al'Āmilī in the Ottoman Empire (991-93/1583-85)", Princeton Papers in Near Eastern Studies, 4 (1996), pp. 1-70.

Stewart, Devin J., "The Identity of 'the Mufti of Oran': Abū al-'Abbās Aḥmad b. Abī Jum ‘a al-Maghrāwī al-Wahrānī (d. 917/1511)", Al-Qanțara, 27, 2 (2006), pp. 265-301.

Strothmann, Rudolf, “Takiyya”, Encyclopaedia of Islam, $1^{\text {st }}$ ed., Leiden, Brill, 1913-36, vol. 8, pp. 628-29.

Al-Suhaylī, Abū l-Qāsim 'Abd al-Raḥmān b. 'Abd Allāh, al-Ta'rīf wa-l-i ' lām fìmā ubhima min al-asmā' wa-l-a 'lām fì l-Qur'ān al-karìm, Beirut, Dār al-Kutub al-'Ilmiyya, 1987. 
Sulaymān b. 'Abd al-Qawī al-Ṭūfì, Kitāb al-ta yìn fì sharh al-Arba 'ìn, Aḥmad Haajj Muhammad 'Uthmān (ed.), Beirut, Mu'assasat al-Rayyān, 1998.

Al-Suyūṭī, Jalāl al-Dīn, Sharh 'uqūd al-jumān fì 'ilm al-ma 'ānī wa-l-bayān, Cairo, Maṭba'at al-Bābī al-Halabī, 1939.

Al-Ṭabarī, Muhammad b. Jarīr, Jāmi al-bayān 'an wujūh ta'wīl āy al-Qur'ān, Cairo, Muștafā al-Bābī al-Halabì, 1954, 30 vols.

Tabataba'i, Allama, Shiite Islam, London, Allen and Unwin, 1975.

Al-Tha' labī, al-Kashf wa-l-bayān, Abū Muhammad b. 'Āshūr (ed.), Beirut, Dār Ihyầ' al-Turāth al-'Arabī, 2002, 10 vols.

Tueller, James B., Good and Faithful Christians: Moriscos and Catholicism in Early Modern Spain, New Orleans, University Press of the South, 2002.

Vernet, Juan, "La exégesis musulmana tradicional en los coranes aljamiados", in Actas del coloquio internacional sobre literatura aljamiada y morisca, Madrid, Gredos, 1978, pp. 123-45.

Al-Wansharīsī, al-Manhaj al-fă'iq wa-l-manhal al-rā’iq, Rabat, Wizārat al-Awqāf wa-1-Shu'ūn al-Islāmiyya, 1997.

Al-Wansharīisì, al-Mi 'yār al-mu 'rib wa-l-jami' al-mughrib, Beirut, Dār al-Gharb al-Islamī, 1981-83, 13 vols.

Yāqūt al-Ḥamawī, Irshād al-arīb ilā ma'rifat al-adīb, D.S. Margoliouth (ed.), London, Luzac, 1907-27, 7 vols.

Zagorin, Perez, Ways of Lying: Dissimulation, Persecution and Conformity in Early Modern Europe, Cambridge, Harvard University Press, 1990.

Al-Zamakhsharī, al-Kashshāf 'an ḥaq'àiq al-tanzīl, Dār al-Mårifa, Beirut, n.d., 4 vols.

Recibido: $06 / 03 / 2013$

Aceptado: 26/04/2013 